\title{
Wojna w twórczości Franciszka Salezego Jezierskiego (zagadnienia wybrane)
}

Bronisław Treger 
ИAP7S Seria VII 2001

\section{Bronisław Treger}

\section{Wojna w twórczości Franciszka Salezego Jezierskiego (zagadnienia wybrane)}

$\mathrm{F}$ ranciszek Salezy Jezierski zamieszcza w Jarosza Kutasińskiego... uwwagach nad stanem nieszlacheckim w Polszcze, słynnym pamflecie, który bez wątpienia należy do najwybitniejszych utworów literatury okolicznościowej polskiego oświecenia, następujący passus:

...ani Homer, ani Wirgilijusz nie pisze w swoich wierszach, kto pierwszy wynalazł sposób pieczenia chleba, gotowania mięsa, nawet ani tego nie wzmiankuje, kto zbudował machinę konia, sławne narzędzie w ich wierszach do wzięcia i obalenia Troi, tylko natomiast piszą o Achillesie, Ulissesie i innych mordercach rodzaju ludzkiego, jakoby była większa zasługa wojować, przenosząc panowanie narodu od narodu, niż uczynić wynalazek albo go pracą utwierdzić dla pożytku, wygody i szczęścia powszechnego wszystkich pokoleń ludzkich ${ }^{1}$.

\section{Chwała wojowania i powszedni mozół pracy}

W powyższym aforystycznie ukształtowanym wyimku zawiera się między innymi odniesienie do dwu idei, znamiennych dla ważkich nurtów duchowości oświeceniowej. Po pierwsze do przemyślanej, racjonalnej, acz wielekroć nieprzebierającej w drwiących i kąśliwych argumentach, krytyce wojny i bałwochwalczego uwielbienia militarnej sławy i chwały przez elity władzy i warstwy z nimi związane. Przykładowo: w haśle Wojna ze Stownika filozoficznego Wolter ${ }^{2}$ nie bez szczypty zgryźliwej zapalczywości oznajmia:

\footnotetext{
${ }^{\prime}$ F. S. Jezierski, Jarosza Kutasinskiego, herbu Dęboróg szlaclucica hukouskiego, uwagi nad stanem nieszlacheckim w' Polszcze, [b.m.w.] 1790, s. 25.

${ }^{2}$ Przywolując idee stanowiące inspirację dla myśli polityczncj, społeczncj i filozoficzncj kanonika, nic będę drobiazgowo zastanawiał się nad ich narodzinami, wędrówką i metamorfozami. Z braku miejsca ograniczę sic̨ do krótkicgo wskazania wybranych wpływowych wytwórców czy popularyzatorów owych idci — współczesnych Jezicrskicmu,
} 
La famine, la peste et la guerre sont les trois ingrédients les plus fameux de ce bas monde. (...) Ce deux présents nous viennent de la Providence. Mais la guerre, qui réunit tous ces dons, nous vient de l'imagination de trois ou quatre cents personnes répandues sur la surface de ce globe sous le nom de princes ou de ministres; et c'est peut-être pour cette raison que dans plusieurs dédicaces on les appelle les images vivantes de la Divinité ${ }^{3}$.

I nieco dalej powiada o postępowaniu wodzów zbrojnych kampanii:

Le merveilleux de cette entreprise infernale, c'est que chaque chef des meurtriers fait bénir ses drapeaux et invoque Dieu solennellement avant d'aller exterminer son prochain ${ }^{4}$. (...)

Philosophes moralistes - woła Wolter w części końcowej hasła — brîlez tous vos livres. Tant que le caprice de quelques hommes fera loyalement égorger des milliers de nos frères, la partie du genre humain consacrée à l'hérö̈sme sera ce qu'il $\gamma$ a de plus affreux dans la nature entière 5 .

Twórczość Woltera jest - rzecz jasna — nieobca kanonikowi. Stownik filozoficzny stanowił inspirację dla Niektórych wyrazów..., dzieła francuskiego myśliciela są cytowane w publikacjach Jezierskiego ${ }^{6}$.

Drugą ideą jest przeświadczenie, iż praca wytwórcza stanowi źródło bogactwa narodów albo przynajmniej fundamentalny warunek tychże. Zapatrywanie, zgodnie z którym trud człowieka to nieodzowny przymiot działalności gospodarczej pomnażającej bogactwo (choć nowo powstała wartość, czysty przychód objawiający się w formie renty gruntowej, jest darem natury możliwym do uzyskania jedynie w rolnictwie), było upowszechniane między innymi przez szkołę fizjokratyczna. Franciszek Quesnay w artykule Zboże z VII tomu Encyklopedii Diderota i d'Alemberta konstatuje:

Dochody są wytworem gruntów i ludzi. Bez pracy ludzkiej grunty nie mają żadnej wartości ${ }^{7}$.

bądź takich spośród wcześnicjszych, co do których istnicje mnicj lub bardzicj uzasadnione przypuszczenic, iż ich dzieła względnie koncepcje były mu znane.

${ }^{3}$ Voltaire, Dictionnaire philosophique, [b.m.r.w.], ( ) Éditions Gallimard 1994, s. 300 („Głód, zaraza i wojna to trzy najbardziej osławione elementy, nieodłączne od tego świata. [...] Takie oto dwa prezenty otrzymaliśmy od Opatrzności. Ale wojnę, skupiającą w sobie wszystkie te dary, zawdzięczamy wyobraźni trzechset czy czterechset osób znajdujących się w różnych miejscach na tym globie i znanych pod nazwą książąt albo ministrów; pewnie dlatego w dedykacjach nazywa się ich żywymi obrazami Boga" - Wolter o życiu, milości i śmierci, wyb. i wst. J. Adamski, Warszawa 1961, s. 16-18, nr 13; notabene w tomie tym, ogłoszonym w ramach wznowionej serii „Sympozjon”, nie wspomniano o poprzednim zbiorze wyimków z fernejskiego filozofa, wydanym dawnicj w tej serii jeszcze pod rcdakcją Leopolda Staffa — zob. niżej).

${ }^{4}$ Ibidem, s. 302 („Ciekawsze w owej piekielnej robocie jest to, żc każdy kierownik band morderczych nakazywał poświęcać swoje sztandary wodą święconą i każdy przywoływał na głowy wrogów swoich — samego Pana Boga”Voltaire, Refleksje, tł. i opr. G. Glass, Lwów 1911, s. 116).

${ }^{5}$ Ibidem, s. 303-304 („Moraliści, spalcie swoje książki! Dopóki kaprys pewnych ludzi każe zarzynać tysiące naszych braci w majestacie prawa, bohaterowie będą zawsze czymśnajpotworniejszym we wszechświecie" - Wolter o życiu..., op. cit., s. 18).

${ }^{6}$ Zob. np. F. S. Jezierski, Niektóre wyrazy porzq̨dkiem abecadta zebrane i stosownemi do rzeczy uwagami objaśnione, Warszawa 1791, s. 62, 92, 188.

7 F. Quesney, Zboże, w: idem, Pisma wybrane, tł. J. Pietkiewiczówna, Warszawa 1928, s. 225. 
Zaś w swych słynnych Maksymach ogólnych rzq̨u gospodarczego w królestwie rolniczym (maksyma III) powiada:

Niech naród i panujący mają to zawsze na widoku, że ziemia jest jedynym źródłem bogactw, i że pomnaża je rolnictwo. Albowiem zwiększenie bogactw zapewnia pomnożenie ludności; ludzie i bogactwa podnoszą rolnictwo, rozszerzają handel, ożywiają przemysł, przysparzają bogactw i utrwalają je. Od tego źródła obfitego zależy powodzenie we wszystkich działach administracji królestwa ${ }^{8}$.

Zaniedbując w tym miejscu kwestię daleko idących jednostronności i uproszczeń w teorii ekonomicznej fizjokratów (wynikających w głównej mierze $z$ absolutyzowania gospodarki agrarnej, a krytykowanych już w XVIII stuleciu), zauważmy, iż w ich nauce po raz pierwszy tak dobitnie i przy wsparciu tak imponującej argumentacji propagowano pogląd, że bogactwo narodów bierze się przede wszystkim ze sfery produkcji, a nie na przykład z handlu czy wojennych podbojów. Krótko mówiąc, to wytwórca (wedle fizjokratów: rolnik), w odróżnieniu choćby od wodzów czy bohaterów wojennych, jest właściwym twórcą potęgi królestw i rzeczypospolitych. Stanowisko szkoły w tym względzie zwięźle referuje ksiądz Hieronim Stroynowski w Nauce prawa przyrodzonego...:

Od stanu więc rolnictwa nie tylko zależy los rolników i właścicielów gruntów, ale nawet los wszystkich ludzi, których umieściliśmy w jednej klasie nazwanej przemysłową, ale nawet pomyślność, bezpieczeństwo i moc całego narodu i najwyższej zwierzchności ${ }^{9}$.

Gdy władcy zapomną o tej prawdzie, prędzej czy później ich kraje wstąpią na drogę upadku. Dotyczy to największych nawet imperiów. Twórca doktryny powiada w Rozbiorze tablicy ekonomicznej:

Rzym umiał zwyciężać i podbijać wiele narodów, ale nie umiał rządzić. Złupił bogactwa rolne krajów podległych jego panowaniu — odtąd znikła jego potęga militarna, odebrano mu jego zdobycze, które go wzbogacały, on zaś sam pozostał bez obrony, wydany na łup i gwałty wroga ${ }^{10}$.

Jak zdają się wskazywać źródła, dla przynajmniej niektórych polityków i publicystów Kuźnicy ${ }^{11}$ problemy ekonomii politycznej były przedmiotem nie tylko powierzchownego zaciekawie-

${ }^{8}$ Ibidem, s. 122. Maksymy... ukazały się po raz pierwszy w polskim przekładzie w „Pamiętniku Historyczno-Politycznym” w 1788 roku (zob.: I. Homola-Dzikowska, „Pamietnik Historyczno-Polityczny” Piotra Świtkowskiego 1782-1792, Kraków 1960, s. 42-44; E. Lipiński, Studia nad historiq polskiej mysli ekonomicznej, Warszawa 1956, s. 439).

${ }^{9}$ H. Stroynowski, Nauka prawa przyrodzonego, politycznego, ekonomiki politycznej i prawa narodów, wyd. 2, Wilno 1791 (wyd. 1. ukazało sic̨ w 1785 roku), s. 195.

${ }^{10}$ F. Qucsncy, op. cit., s. 109.

"Terminu 'Kuźnica' używam tu zgodnie ze znaczeniem wyszczególnionym przez Jerzego Koweckiego: „Kuźnicę tworzyło grono związanych z nim [Kołłątajem - B. T.] w różnych okresach Sejmu Czteroletniego - niejednokrotnie trwale i ściśle, ale w innych wypadkach względnic luźno i przejściowo - pisarzy, publicystów, prawników oraz działaczy politycznych i agitatorów. $\mathrm{O}$ istnieniu tego grona jako politycznego zespołu działaczy decydowała wybitna indywidualność przywódcy - jedynego wśród nich polityka wielkiego formatu, który przyciągał do współpracy i w różnym stopniu podporządkował sobie pozostałych" (idem, Kuźnica Kollątajowska — legenda czy rzeczyuistość historyczna?, „Kwartalnik Historyczny”, R. 85, 1978, s. 1021-1022). 
nia. O stopie znawstwa rzeczonej tematyki w owym kręgu można się rozeznać na przykładzie uwag samego Kołłątaja, rzuconych w III części Listów Anonima... przy okazji omawiania materii podatkowych:

Nie widziałem nic rozsądniejszego w ekonomii politycznej nad układ ekonomistów [fizjokratów - B. T.]. Wszakże mało się kto podobno zastanowił, iż wszelka robota ludzka, oprócz łożonych na zakład początkowy kosztów, musi mieć swój procent, to jest intratę czystą. Wiele zaś jest takowych, którzy mają bez porównania większy i lepszy procent, jakby go nigdy w ziemi naleźć nie mogli, na przykład ten, który około brylantów pracuje lub handel nimi prowadzi; malarz lub snycerz sławny, rzemieślnik, który z kitki lnu pięć groszy wartującego zrobi koronkę kosztującą kilkaset czerwonych złotych. (...) Ręka i przemysł pracowitego człowieka w każdej części świata, na każdej ziemi umie sobie samej wystarczyć. (...) sama tylko ręka człowieka i potrzeba jego tak surowej, jako i przerobionej reprodukcyi nadaje szacunek i jest do wszystkich bogactw jedynym kluczem ${ }^{12}$.

Oczywiście, daleko idącą przesadą jest snucie na podstawie takich i podobnych wypowiedzi Kołłątaja rozmyślań o dokonanej podobno przez referendarza litewskiego pogłębionej krytyce systematu fizjokratycznego, o rozwinięciu postępowych elementów zawierających się w owej teorii czy też rozważań o przypuszczalnym czerpaniu przez autora Listów Anonima... inspiracji $z$ dzieła Adama Smitha ${ }^{13}$. Znacznie prostsza i, jak się zdaje, bliższa prawdy będzie następująca interpretacja: w passusie, $z$ którego pochodzą przywołane tu wyimki, przyszły autor Porzqdku fizyczno-moralnego rzuca propozycję uzgodnienia teorii fizjokratycznej i merkantylistycznej. Po krótkim zreferowaniu poglądów Ferdynanda Galianiego (1728-1787), włoskiego zwolennika merkantylizmu oraz krytyka zapatrywań fizjokratycznych, i przytoczeniu jego słynnej formuły „człowiek jest skarbem najdroższym”, Kołłątaj przedstawia własne stanowisko:

Ja zaś, trzymając śrzodek między tymi dwiema ważnymi opinijami, ziemię nazwałem jedynym bogactw skarbem, a rękę człowieka kluczem, bez którego bogactw rzeczonych dostąpić nie można. Człowiek więc i ziemia są wspólną przyczyną masy bogactw, a zatem czyli byśmy przez przyczyny szli do skutków, czyli z skutków dochodzili przyczyn, jedne okażą się wypadki ${ }^{14}$.

${ }^{12}$ H. Kołłątaj, Listy Anonima i Prawo polityczne narodu polskiego, opr. B. Leśnodorski, H. Wercszycka, t. 2, Warszawa 1954, s. $61,63$.

${ }^{13}$ „Gdyby zatem Kołłątaj - pisał Bogusław Leśnodorski we wstępic do Listów Anonima... - bezpośrcdnio lub opierając siç na informacji i wskazówkach Ossowskiego, mógł znaleźć podnietę w wywodach Adama Smitha na temat pracy produktywnej i nieproduktywncj, na temat wartości itd., oczywiścic oryginalność jego poglądów mogłaby się okazać mnicjsza. Ale nic to jest najważniejsze. Istotne jest, że Kołłątaj dokonał krytyki fizjokratów i że wyzyskał ją dla konkretnych postępowych celów politycznych. Dokonał zaś tej krytyki w oparciu o własne i ogólniejsze doświadczenic, o szeroko pojętą praktykę. Pisarz polski rozwinął tkwiące u fizjokratów francuskich zarodki koncepcji burżuazyjnych, które później, w pracach ściślc już naukowych, miał jeszcze pogłębić od strony teoretyczno-filozoficzncj" (H. Kołlątaj, op. cit., t. 1, s. 81-82).

${ }^{14}$ Ibidem, t. 2, s. 134. 
Nietrudno zauważyć, iż wypośrodkowane przeświadczenia ekonomiczne referendarza litewskiego uznają pracę ludzką — także tę spoza rolnictwa — za jeden z najgłówniejszych czynników bogactwa i rozkwitu narodów, i co za tym idzie, dowartościowują działalność gospodarczą miast bądź z miast się wywodzącą: rzemiosło, handel, manufakturę...

Podobne stanowisko da się odczytać z tekstów Jezierskiego, najwybitniejszego z publicystów, których referendarzowi udało się pozyskać do współpracy w Kuźnicy. W Rzepisze... został pomieszczony następujący wywód:

Taki jest obrządek Opatrzności, w narodach osobliwie rolniczych; poziomego rodu lud przywiązany pracą do ziemi wyrabia sobie pożywienie, a panom własną pracą przystawia zbytki. Rodzaj Piasta dziełami sił swoich sprowadza przysmaki do stołów pańskich, które są płodem ziemi w czterech częściach świata, i kiedy natura pracuje wiekami, aby we wnętrznościach ziemi wylagł się kruszec złota na potrzeby bogatych, wtenczas ród Piasta, w kraju swoim przewracając pługiem powierzchnią ziemi w zagony, wyciąga z niej pożytki rolnictwa, a te, istotną będąc życia potrzebą, mimo niezmierną rozległość morza i ziemi sprowadzają na swój zamian złoto ${ }^{15}$.

Nieco dalej sam Piast - porte-parole księdza Franciszka Salezego - wygłasza mowę na cześć trudu najpierw rolnika, w późniejszej kolejności zaś rzemieślnika i kupca:

Wychowanie bydła pomnaża kraj w rośliny zboża, a obfitość zboża utrzymuje stajnie, owczarnie i obory dobytków, te są bogactwa naszego kraju wyznaczone za pierwszą potrzebę w naturze, resztę zaś są ${ }^{16}$ tylko wymysłów ludzkich zachceniem. Potrzeba nam pamiętać, że słowiańska ziemia jest jak dla dziecięcia mamka z pokarmem dla inszych narodów, przeto tu trzeba obrócić pracę, rozum i usiłowanie obojga tego, aby dary w domu moim rozmnożone powiększały się, żeby naród nasz zawsze częstował sąsiadów chlebem i mięsem. (...) Jeżeli się ziemia z zarośli, lasów i ścieku błot oczyści, jeżeli pomnożenie bydła i pszczół zwiększy się w narodzie, dopiero otworzy się droga rzemiesłom i kupiectwu, bo każdy człowiek musi żyć, a gdy nie wystarcza ziemi ludziom, dopiero obracają przemysł do tego, co zbywa nad ziemią i nad jej przyrodzonemi korzyściami ${ }^{17}$.

Twórcza potęga pracy jest zadziwiająca - kanonik z niekłamanym uznaniem odnosi się do wytrwałości i przemyślności Holendrów pokonujących siły natury i przerabiających mokradła na urodzajne pola i bezpieczne siedliska. Wydarte naturze zdobycze twórczego mozołu rąk oraz umysłów są z reguły trwalsze, a także pożyteczniejsze dla jednostek i społeczności niż łupy zagarnięte brutalną przemocą oręża. Główny narrator jednego z utworów - widziadło senne, wojewoda sandomierski Goworek — wspomina, iz:

15 F. S. Jezicrski, Rzepicha, matka królów, żona Piasta, między narodami sarmackiemi slowiańskiego monarchy tej częśi ziemi, która się nazywa Polska, Warszawa 1790, s. 301-302.

${ }_{16}$ W pośmiertnym, 2. wyd. Rzepichy... (Warszawa 1794, s. 229) mamy: „rcszta zaś jest”.

17 F. S. Jezicrski, op. cit., s. 317-319. 
Batawija, co jest dziś piękną, bogatą i wolną Holandyją, była za mego czasu resztą Renu, przerabiającego kraj ów z ziemi na błoto ${ }^{18}$.

W Tronie dla próżnej powagi... czytamy:

Jest $\mathrm{w}$ naszej części świata na samym pobrzeżu morskim lud, który granicząc z ziemią kilku narodów nie może się sam nazwać mieszkańcem prawdziwym ziemi; są to obywatele morza, na nim mając korzyści i sposób swojej bytności na świecie, osadę zaś lądową mają w mieszkaniu na błocie, gdzie przemysł i praca kłócąc się $[z]$ przyrodzeniem zrobiła mieszkanie honor czyniące rozumowi i wolności człowieka ${ }^{19}$.

Praca stanowi fundament siły — również militarnej — narodów:

Tak ci jest: ogromne obozy, świetne ubiory rycerstwa! Wy jesteście dobrodziejstwem rolniczego Piasta utrzymywane. Mocy narodów zasadą gruntowną praca rolnika. Panowie przedwieczni próżniacy swarzą się o posiadanie stopni i dochodów wojskowych, rzadko kiedy zdolnymi będąc dopełnić ich sposobnością osobistą, gdy każdy rolnik wszystką siłą pracuje na nich ${ }^{20}$.

Kiedy ksiądz Franciszek Salezy każe niepokornemu akademikowi instruować Jarosza Kutasińskiego, iz:

Ten prosty człowiek, który najpierwszy sposób wynalazł solenia śledzi, choć był wzgardzony ze swego sposobu życia przez rozumienie przesądu, przecież on się stał dobrodziejem narodu, sprowadził milijony zarobku swemu krajowi i więcej dokazał jak wszystkie urojonej wielkości zaszczyty ${ }^{21}$

- to w owych pouczeniach dochodzi do głosu nie tylko przekorność i zamiłowanie do paradoksu, lecz również głębsza ${ }^{22}$, oparta na niebanainej podwalinie teoretycznej myśl o twórczej

${ }_{18}$ Idem, Gowórek herbu Rawicz, wojewoda sandomirski. Powieśc z widoku we śnie, opr. B. Trcger, „Napis”, seria VI, 2000, s. 135.

${ }^{19}$ Idem, Tron dla próżnej powagi, szlachta do poddaństwa..., opr. B. Treger, „Napis”, scria IV, 1998, s. 125.

${ }^{20}$ Idem, Rzepicha..., op. cit., s. 302-303.

${ }^{21}$ Idem, Jarosza Kutasińskiego... uwagi..., op. cit., s. 23-24.

${ }^{22}$ Warta podkreślenia jest wyobraźnia społeczna, historyczna i polityczna, przejawiająca siç niejednokrotnic $\mathrm{w}$ aforystycznych fragmentach pism kanonika. W tych - jak się bardzo często wydaje na pierwszy rzut oka - tylko satyrycznych czy paradoksalnych urywkach po dokładniejszym rozpatrzeniu można zauważyć konstatacje, pomysły, idee, które swej trafności nie zagubiły mimo upływu lat. Jeden z najwybitniejszych dwudziestowiecznych historyków $i$ historiozofów Fernand Braudel tak pisze o znaczeniu handlu solonymi śledziami dla gospodarki Holandii w trzecim, sumującym tomie pt. Czas świata, swojej trylogii Kultura materialna, gospodarka i kapitalizm XV-XVIII w.: „Solone lub wędzone śledzie, sprzedawanc w całej Europie, są holenderską «kopalnią złota». (...) Sir George Downing (8 lipca 1661 r.) zauważył chłodno: «handel śledziem ożywia handel solą, a śledź i sól są przyczyną rozwoju holenderskiego handlu na Bałtyku»; dorzućmy od siebie, że handel bałtycki stał się prawdziwym źródłem holenderskiego bogactwa" (F. Braudel, op. cit., tł. J. i J. Strzeleccy, Warszawa 1992, s. 166). Niezależnie od dyskusji na temat względnej roli rybołówstwa w ekonomice Zjednoczonych Prowincji poważny udział tej gał̨zi gospodarki w budowic potęgi Holandii nie podlega wątpliwości. A była to swego czasu potęga o znaczeniu ogólnoświatowym, państwo i społeczeństwo przecierające szlaki rozwoju ludzkości. U Braudela czytamy: „Pierwszy etap holenderskicj wielkości 
mocy cywilizacyjnej tej pracy duchowej i fizycznej człowieka, która przyczynia się do rozwoju produkcji gospodarczej (w przeciwieństwie do rozprzęgającego, niszczycielskiego żywiołu wojen i podbojów).

W jakim kontekście pomieścił kanonik Jezierski przywołany na samym początku niniejszego szkicu oraz rozpatrywany tu urywek z Jarosza Kutasinskiego... uwag. . . ? Gdy narrator pierwszoosobowy wzmiankowanego pamfletu po kilkuletnim znojnym trudzie nauki laciny dotarł do klasy poetyki, jego zainteresowanie wzbudziły zajęcia poświęcone objaśnianiu i komentowaniu Eneidy Wergilego. Pewnego razu zwrócił się do wykładowcy z prośbą o rozświetlenie intrygującej go kwestii szczegółowej. Szło mu o to, czy starożytni herosi rodzili się ze szlachty i czy tak jak on pieczętowali się herbami. Profesor ${ }^{23}$ nie zbył lada czym naiwnego pytania uczniaka, wykorzystał okazję, by obznajomić go — w dłuższej prelekcji — z istotą i pochodzeniem przesądu o wyższości szlachty nad innymi warstwami społecznymi, w szczególności nad stanem miejskim. Przemowa nauczyciela stała się zarodkiem zwątpienia w duszy Kutasińskiego. Dogmatyczne zapatrywania i legendy o kastowej przewadze szlachty nad mieszczaństwem wyniesione $z$ rodzinnego domu powoli przestają być dla niego niepodważalnym pewnikiem. Później sam zauważy:

Rodziemy się na to, abyśmy żyli, a żyjemy na to, abyśmy myślili, jak kiedy sądziemy o rzeczach i dlaczego w czasie odmieniamy nasze przeszłe rozumienie o nich ${ }^{24}$.

Ześrodkowanie przez Jezierskiego tematyki pamfletu na kwestii mieszczańskiej nie wzbudza zdziwienia - bezpośrednią pobudką do literackiej analizy umysłowości łukowskiego szlachetki, jego wyobrażeń o niezmierzonej przewadze urodzonych nad sławetnymi (pracowici nie są nawet godni dłuższej wzmianki) był jeden z epizodów zmagań politycznych w czasie Sejmu Czterolet-

gwarantowała Europa. Drugim etapem był świat. Czy drugic nic było jednak po czçści następstwem picrwszego? Gdy Holandia opanowała curopejski handel, klucze świata wpadły w jej ręce niemal bez żadnego wysiłku" (ibidem, s. 181). Rzecz jasna, celem ninicjszego przypisu było jedynie zwrócenie uwagi na niezgorszą intuicję historyczną Jezierskiego, w żadnym zaś wypadku czynienie zeń prekursora historiografii „długiego trwania”.

${ }^{23}$ Wywody profesora opatruje Jezierski takim oto przypiskiem: „Jeden akademik wizytujący szkoły, gdy w podobnym sposobie myślenia o szlachcie mówił do młodzicży szkolnej w jednej prowincyi, takie to zrobiło oburzenic scre najpierwszych obywateli, iż przeciw niemu podano oskarżenie do przełożeństwa nauk krajowych, od którego został ukarany złożeniem z urzędu i pozbawieniem stanu akademickicgo, w którym kilka lat pracował" (F. S. Jezicrski, Jarosza Kutasińskiego... uwagi..., op. cit., s. 24). Jest to jedyna wzmianka autobiograficzna w tym utworze (por. J. Michalski, [rec.] Franciszek Salezy Jezierski, „Wybór pism”. Opracowval Z. Skwarczyński PIW, 1952, „Przcgląd Historyczny”, t. 44, 1953, s. 628). Kanonik nawiązuje w tym miejscu swego pamfletu do incydentu zaszłego w trakcie odprawianej przezeń wizyty szkół podwydziałowych łęczyckich. Przedstawiciele miejscowej szlachty wzic̨li w obronę tamtejszych akademików, kąśliwic krytykowanych przez Jezierskiego, i wystosowali taką oto skargę na wizytatora, zawartą w instrukcji dla wysłanników, mających się udać do prymasa Michała Jerzego Poniatowskiego: „Nie przepomną ciż J. W. Delegowani użalić się imieniem całego województwa naszego przed Jaśnic Oświeconym Księciem Jegomością prymasem na Imci ks. Jezierskiego, wizytatora generalnego szkół, który po to jedynie zdał się przybył, aby w uszach dzieci naszych zhańbił i znieważył nas wystawiając obelżywie w przemowic swojcj do młodzieży mianej rodziców na cel szyderstwa, a satyryczną krytyką swoją dotykając ordery, urzçdy, sądowe magistratury i cały stan rycerski. Dopraszać się oraz będą o przyzwoitc tegóż Jegomości ks. Jezierskiego ukaranie" (Teki Pawińskiego, nr 13, Akta sejmikowe województwa łęczyckiego IV 1733-1792, k. 715-716, rps Bibliotcki PAN w Krakowie 8330. O owym zajściu napomykam nieco szerzej — przywołując ważniejszą literaturę przedmiotu - w szkicu Kaznodzieja i prześmiewca. Uwagi o niektórych zagadnieniach twórczości i życia Franciszka Salezgo Jezierskiego, „Napis”, scria V, 1999, s. 103-104, 112).

${ }^{24}$ F. S. Jezierski, Jarosza Kutasiniskiego... uwagi..., op. cit., s. 11. 
niego: memoriał miast i potyczki publicystyczne przezeń wywołane ${ }^{25}$. Ważnym rysem swoistym metody pisarskiej ${ }^{26}$ kanonika jest umiejętność przechodzenia od najgorętszych nawet kwestii politycznych chwili bieżącej do mniej lub bardziej pogłębionych, nierzadko cechujących się aforystyczną zwięzłością i paradoksalnością rozważań o naturze człowieka i społeczeństwa. Krótko mówiąc, pod piórem Jezierskiego doraźna publicystyka polityczna zadziwiająco często przekształca się w zajmujące intelektualnie i błyskotliwe literacko próby, fragmenty czy szkice zaryzykujmy użycie uczonej terminologii — psychologiczne, socjologiczne ${ }^{27}$, historiozoficzne... W'́ród tych ostatnich dość często pojawiają się rozmyślania poświęcone wojnom i rozmaitym materiom z rozgrywkami i kampaniami zbrojnymi związanym.

Z pokrewną pod pewnymi niebłahymi względami kompozycją literacką, co w Jarosza Kutasińskiego... uwagach mamy do czynienia w Rzepisze... I w jednym, i w drugim utworze beletrystyka jest podporządkowana publicystyce. Fabuła spełnia tu między innymi dwa ważne zadania. Po pierwsze stanowi stabilną konstrukcję nośną, umożliwiającą swobodniejsze rozlokowanie ciężkiej niekiedy dla szerszej publiczności materii rozważań i dyskusji politycznych (a także moralnych, społecznych, filozoficznych...); po drugie jest ozdobnym opakowaniem, mającym skusić jak najwięcej potencjalnych czytelników do lektury. Przy takich założeniach kompozycyjnych zasadnicza odmienność fabularna obu dzieł w najmniejszym stopniu nie zaciemnia identyczności zawartego w nich politycznego, a także ideowego przesłania. Wątłą akcję Rzepichy... można śmiało pominąć w trakcie rozpatrywania pomieszczonych w niej koncepcji myślowych.

W przywołanej książce najbardziej chyba dobitnie wysłowił Jezierski myśl o niewspółmierności między rzeczywistymi zasługami dla dobra ludzkości jednostek i grup stosunkowo nisko usytuowanych w hierarchii społecznej, zajmujących się wynalazczością i pracą produkcyjną, a osobliwym brakiem należytego uznania dla ich osiągnięć oraz trudu w literaturze, sztuce, historiografii czy wreszcie w praktyce prawnej i państwowej. W przeciwieństwie do lekceważonego świata pracy elity militarne pławią się w blasku sławy i chwały, choć dla wspólnego dobra nie przyczyniają się na ogół wcale (najczęściej dobro to w mniejszym lub większym stopniu unicestwiają). Aby wyraziście i przystępnie wypowiedzieć owo przesłanie, kanonik w znamienny dla siebie sposób nie stroni od paradoksu, satyry i anegdoty:

\footnotetext{
${ }^{25}(\ldots)$ wśród tych więc obrad miasta koronne i litewskic wysłały osoby z zgromadzeń micjskich do Warszawy, gdzie złączeni razem wysłańcy z miast napisali żądania stanu swojego do króla i sejmu. Postępck taki zdał sic̨ zaraz niewiadomości, przesądom i uprzedzeniom niezwyczajnością, nieprzystojnością i na koniec nicsłusznością, Prawda i nieprawda obydwie podniosły swój głos niosący zdania. Wyszło mnóstwo pism przeciwnych nawzajem; dzicje i prawa narodu przywiedzione na świadectwo tej wielkiej matcryi: czyli micszkańce miast mają być osobami w tak obszernej Rzeczypospolitej?" (ibidem, s. 6).

${ }^{26}$ Wybrane zagadnienia metody pisarskicj kanonika starałem się wstępnic zarysować w szkicu: „Gowórek herbu Rawicz...” a niektóre wtaściwości metody pisarskiej Franciszka Salezego Jezierskiego, „Napis”, seria VI, 2000, s. 119-127.

${ }^{27}$ Przykładowo - Włodzimierz Bolecki w komentarzu krytycznym do Diogenesa w kontuszu Waclawa Berenta pisze: „Tematem Jarosza Kutasińskiego... są zatem przesądy, mity i uprzedzenia jako formy myślenia warstw czy klas społecznych. Jest to jakby literacko przedstawiona problematyka socjologii wiedzy" (W. Berent, Opowieści biograficzne, opr. W. Bolecki, Kraków 1991, s. 465).
} 
Są to prawie zwyczajne postępowania wyroków Opatrzności, iż ona więcej przez osoby niskiego i ubogiego majątku uczyniła dobrodziejstw ludziom, niźli przez tych, co większością okazałych dzieł i świetnością chwały własnej zarzucili dzieje narodów. Kiedy wojną wiary chrześcijańskie mocarstwa zapaliły Europę przeciwko Azyi, aby utrzymać się przy Palestynie, dzieła wielkich wodzów i zwyciężców, wycedziwszy krew z milionów ludzi i wydarłszy im życie, sprowadziły nam w pożytku do Europy zarazę powietrza, świerżby i ospy; wtenczas z prostego gminu Saracenów ubogi derwisz jeden w zaciszu swojego życia na górze Iman upatrzył roślinę kawy, i doszedłszy pożytku z jej ziarna gotowal obfite zyski swej ojczyźnie z tego ziemi krajowej płodu. Komuż winniśmy cykulaty ${ }^{28}$, cukry i tyle miłych smakowi przypraw? Oto Indyjanom nagim; czarnym, nędznym i ubogim Murzynom! Takie są wyroki zarządzającej Opatrzności, że więcej niewolnicza ręka ${ }^{29}$ zjednała korzyści, jak wyniesione ramię zwycięzcy zrobiło szczęścia i dobra dla ludzi; przecież dźwiga ziemia posągi bohatyrów, chwałę ich ogłasza pamięci wybór dowcipu w pismach, a lud istotnie dobroczynny zostaje pogrzebiony w zapomnieniu, bytność jego współ-

${ }^{28}$ Cykulata - czckolada, zob. np. S. B. Linde, Slownik jezyka polskiego, t. 1, Lwów 1854, s. 338, 312.

${ }_{29} \mathrm{~W}$ uporczywym podkreślaniu przez księdza Franciszka Salezego żywotnego — w wymiarze ogólnoludzkim znaczenia pracy wytwórczej jednostek należących do zbiorowości z najniższych szczebli drabiny społeczncj dochodzi do głosu nie tylko mnicj lub bardzicj zdecydowany radykalizm polityczny, ale takżc przcjawia siç w embrionalncj postaci fragmentów, aforyzmów, anegdot, paradoksów, satyrycznych bon motów et cetera zapatrywanic historiozoficzne, z którym sic̨ można zgadzać albo i nie, ale którego nie można lekceważyć. Bez nadmiernych wątpliwości da się stwierdzić, iż niezgorszą pobudką do zastanawiania się nad celnością przynajmniej niektórych intuicji i pomysłów społeczno-filozoficznych Jezierskiego może być dla historyka idei fakt, że cywilizacyjny czy wręcz historiozoficzny wymiar pracy ludzkicj - w szczególności niewolniczej - staje się przedmiotem analiz w jednym z największych systemów filozofii dzicjów. Oto co pisał G. W. F. Hegel w kilkanaścic lat po śmierci kanonika w słynnym rozdziale Fenomenologii ducha pod tytułem Samoistnośc i niesamoistnośc samowiedzy, panowanie i niewola: „Nicwolnik jako samowiedza w ogóle, odnosi się również negatywnie do rzeczy i ją znosi, ale rzecz jest dla niewolnika jednoczcśnic czymś samoistnym i dlatcgo przez swą negację nic może sobie poradzić z nią tak, żcby ją unicestwić; to zaś znaczy, żc on ją tylko formuje przez swą pracę. Panu natomiast to pośrednictwo niewolnika umożliwia bezpośredni stosunck do rzeczy polegający na czystym jej negowaniu, czyli korzystanie z nicj i rozkoszowanic się nią" (G. W. F. Hegel, Fenomenologia ducha, t. 1, t1. A. Landman, Warszawa 1965, s. 222).

Nieco dalej niemiecki filozof następująco rozbudowuje swoje docickania: „Pożądanic zastrzegłodla sicbic czyste negowanie przedmiotu i - co za tym idzic - niczmącone poczucie własnej pewności. Ale to zadowolenic pozostaje tylko czymś przemijającym, brak mu bowiem strony przedmiotowej, czyli trwania. Praca natomiast jest pożądanicm hamowanym, zanikanicm powstrzymywanym, innymi słowy praca kształtujc. Negatywny stosunck pracującego do przedmiotu staje sic̨ formą tego przedmiotu i czymś trwałym, właśnic dlatego, że dla pracującego przedmiot jest czymś, co posiada samoistność. Ten negatywny człon średni, czyli czynność formująca, jest jednoczcśnic jednostkowością świadomości, tzn. jej czystym bytem dla siebie, który teraz w pracy wychodzi poza siebie i wstępuje w clement trwałości. W ten więc sposób pracująca świadomość dochodzi do tego, że ogląda byt samoistny jako sicbic samą" (ibidem, s. 225-226).

Rozdział o dialcktyce panowania i niewoli to tekst, do którego często odwoływano się w antropologii i filozofii społeczncj drugicj połowy XX wicku. Alexandre Kojève w wykładach o Heglu, które oddziałały inspirująco na całe pokolenie myślicieli francuskich, tak oto objaśnia przewodnią idę̨ wymienionej partii dzicła Hegla: „Człowickiem całościowym, absolutnic wolnym, ostatecznie i całkowicie zaspokojonym tym, czym jest, człowickicm, który w tym i dziçki temu zaspokojeniu dochodzi do swego pełnego urzeczywistnienia i do swej doskonałości będzic Nicwolnik, który zniósł swą niewolę. Skoro próżniacze Panowanie jest impasem, to pracowita Nicwola, przeciwnic, stanowi źródło wszelkicgo ludzkiego, społecznego, historycznego postępu. Historia jest historią pracującego Nicwolnika. Ażeby to stwierdzić, wystarczy rozważyć stosunck między Panem a Nicwolnikiem (tzn. pierwszy rezultat "picrwszego» ludzkiego, społecznego, historycznego kontaktu) już nie z punktu widzenia Pana, ale z punktu widzcnia Nicwolnika" (A. Kojève, Wstęp do wyktadów o Heglu, tł. Ś. F. Nowicki, Warszawa 1999, s. 24). 
czesna na świecie jest okryta pogardą, z ohydą rozumu i serca $w$ dzisiejszym jeszcze wieku zostawiona na złość ludzkości po tylu narodach bez opieki prawa ${ }^{30}$.

\section{Wojna a przesądy i ułudy wieku oświecenia}

Kult wojennej sławy i zaszczytów, zajmujący poczesne miejsce w umysłach wielu przedstawicieli warstwy rządzącej w krajach europejskich, to — jak uważa kanonik — jedna z namiętności walnie przyczyniających się do rozniecania pożóg wojennych:

I tak obłuda, fałszywe obietnice chytrych monarchów albo ich ministrów obracają krocie tysięcy nieszczęśliwego i niewolniczego poddaństwa na zabój, chowają na ten zamiar gromadne wojska z uciśnieniem całego krajowego społeczeństwa i na ten jedynie koniec ${ }^{31}$, zeby gadano w Europie, że ten dwór dziś wiele znaczy albo jego gabinet. Trzebaż podeptać święte prawa ludzkości, ażeby ta sama nędza natury ludzkiej, którą jest wojna, była wyszukańszym sposobem nędzą, żeby przechodziła przez światło poznania i wybór dowcipu, którego by według wszelkiej prawdy na to zażyć należało, aby uniknąć wojny i jej nakładów ${ }^{32}$.

Próżność i megalomania królów, książąt, ministrów i innych polityków czy wodzów, rojących o glorii Aleksandrów, Scypionów, Cezarów, nie przejmuje się prawdami wskazywanymi przez światło poznania. Kultura dworska wieku oświecenia ma do rozumu bardzo często stosunek instrumentalny. Kiedy to wygodne, przymyka się oczy na głoszony kult racjonalności, i hołduje przekonaniom nijak nie dającym się pogodzić z krytycznym rozsądkiem; przekonaniom, które bez zbytniej obawy o zarzut braku umiaru można nazwać przesądami.

Wiek nasz mówiemy oświecony — przygania ksiądz Franciszek Salezy — a w nim najbardziej lubią ludzie karmić gust swój mniemaniem fałszywych wyobrażeń. Przesąd przystawił do dzieł krwawych: morderstwa i okrucieństwa farby cnoty, nazwano to honorem, sławą, a same rozlewanie krwi - męstwem; wynaleziono zaszczyty, nadgrody, obchodzą uroczystością powtarzaną latami przytrafiania zwycięstw ${ }^{33}$.

Wzmacniając i ubarwiając swe zarzuty przeciwko bałwochwalczej gloryfikacji wojowania, Jezierski opowiada w wolterowskim stylu następującą satyryczną dykteryjkę:

Ja nie wiem, gdyby był taki w naturze przypadek, iżby się trzydzieści tysięcy niedźwiedzi mordowało z drugą także tak liczną kupą, czyli by sobie potym te bestyje liczyły za słodycz w swojej pamięci i sercu przypomnienie tego okropnego zdarzenia? ${ }^{34}$

\footnotetext{
${ }^{30}$ F. S. Jezierski, Rzepicha..., op. cit., Warszawa 1790, s. 226-228.

${ }^{31} \mathrm{Tu}$, rzecz jasna, wyraz „koniec” w znaczeniu „cel, zamiar, zamysł”, zob. np. S. B. Linde, Slownik jezyka polskiego, t. 2, Lwów 1855 , s. 429.

${ }^{32}$ F. S. Jezierski, Rzepicha..., op. cit., s. 26.

${ }^{33}$ Ibidem, s. 26-27.

${ }^{34}$ Ibidem, s. 27.
} 
W dużej mierze również przeciwko praktykom spotykanym, nie tak znowu rzadko, w Europie doby oświecenia kieruje kanonik poniższą gorzką, acz nie pozbawioną barwnych retorycznych konceptów filipikę:

Wystawuje chełpliwa potomność posaggi z kamienia i spiżu na zakład pamięci o rozlewcach krwi ludzkiej, aby były tak przykrym ciężarem w ugnietaniu ziemi, jak oni w czasie swojego życia zostawali uciskającymi ludzi, a gdy obracali w perzynę miasta i osady krajów, gdy zabijali krocie tysiąców ludu, zdawało się im nazwisko okazalsze zwycięzcy jak dobroczyńcy. Wieniec wawrzynu ozdabiał ich skronie włożony przesądnym zwyczajem mimo ustawę świętej prawdy - bo gdyby laur wyznaczyła natura na uwieńczenie morderców ludzkich, naówczas ta nikczemna roślina w swym przyrodzeniu nie warta by kwitnąć i posiadać własnego zapachu. I myśleć by można, że w ogrodach niemych są takież same przesądy jak między ludźmi, jeżeliby laur zakwitnął na to, żeby był ozdobą i pomocą do przerobienia nazwiska wielkiego zabójcy na wielkiego zwycięzcy ${ }^{35}$.

Poczucie wyższości, z jakim częstokroć spoglądają oświeceni na dawniejsze dzieje, nierzadko jest całkiem bezpodstawne. Pouczającym przykładem są wojny toczone przez armie podległe różnym - mniejszym lub większym - filozofom na tronie. Barbarzyństwo, bestialstwo, łotrostwo i cyniczna nieprawość nie stały się wcale zjawiskiem odosobnionym podczas kampanii prowadzonych w epoce mieniącej się wiekiem światła i rozumu.

Daremne są te zaszczyty światła rozumu — zauważa kanonik — któremi się chełpi czas życia naszego, jakby on $z$ pomnożonemi wiekami nabrał większej mocy do sprawiedliwości; gdzie uprzedzenie w rozumie namiejętnością ${ }^{36}$ zastępuje drogę do wstępu prawdzie, tam zawsze serce pozostać musi w swego okrucieństwa dzikości, i z powagi zwyczaju wystawia niepodobieństwo dopełnienia słuszności. Miała dzielność prawda w wykonaniu sprawiedliwości od ludzi wielkich w wiekach grubych na zawstydzenie naszego oświeconego wieku ${ }^{37}$.

Powyższe zarzuty ilustruje Jezierski — na zasadzie kontrastu — dwoma przykładami, jednym z przeszłości, drugim z doby sobie współczesnej:

Kazimierz W[ielki] syn Władysława Kokietka, żeniąc się z córką Gedymina książęcia lit[ewskiego], miasto posagu w jakich skarbach prosił teścia o uwolnienie brańców narodu polskiego ${ }^{38}$, nad którym miał panować; to było w wieku XIV,

${ }^{35}$ Ibidem, s. 398-399.

${ }^{36}$ Forma zanotowana w słowniku warszawskim jako gwarowa, zob. J. Karłowicz, A. Kryński, W. Nicdźwiedzki, Stownik jezzka polskiego, t. 3, Warszawa 1904, s. 100. W2. wyd. Rzepichy... (Warszawa 1794, s. 166) jest: „namiçtnością”. ${ }^{37}$ F. S. Jezierski, Rzepicha..., op. cit., s. 228-229.

${ }^{38}$ Opowieść o jeńcach pochodzi od Długosza, który pod rokiem 1325 zapisuje w swoich Kronikach: „Król polski Władysław wysławszy zatem swatów prosił Gedymina podówczs wiclkicgo księcia litewskiego, żcby jcgo synowi, księciu Kazimicrzowi dał córkę za żonę i żeby ta przyniosła ze sobą jako posag nic złoto ani srcbro (tych bowiem rzeczy nie micli wówczas Litwini), lecz zwróconych wszystkich jeńców, których Litwini w poprzednich latach zabrali 
a w wieku XVIII za czasów naszych książęta niektórzy niemieccy przedawali piechoty ludu swojego na okrutną wojnę w Ameryce za gotowe pieniądze, tak właśnie jak my przedajemy im woły, konie i wieprze ${ }^{39}$.

Zarzut okrucieństw wojennych, które w wydaniu osiemnastowiecznym są nieraz daleko bardziej oburzające niż te, które miały miejsce w wiekach zwanych ciemnymi czy gotyckimi, pojawia się wielokrotnie $w$ różnych pismach kanonika. We wspomnianym tu już dziełku zjawa senna, wojewoda Goworek, wypowiada między innymi następujące spostrzeżenie:

Choć wy nazywacie wiek wasz ośmnasty oświecony i pełen ludzkości, a nasz dwunasty dziki i okrutny — jednakże ani u nas jeńców, podwajając ich niewolą, nie zaprzedawano pod cudze panowanie, ani im rąk nie ucinano, cechując nieszczęśliwych do śmierci kalectwem, a zostawując przy nieszczęśliwym życiu na dowód ludzkości w ośmnastym oświeconym wieku ${ }^{40}$.

Słowa Goworka są aluzją do postępowania wojsk dowodzonych przez generałów Semiramidy Północy ${ }^{41}$ w czasach konfederacji barskiej. W innym miejscu ksiądz Franciszek Salezy w następujący sposób wyraża potępienie owych barbarzyństw:

Wojska narodu nazwanego od stolicy [Moskwy - B. T.], podług swego okrutnego przyrodzenia, zabranych sprzymierzeńców [konfederatów - B. T.] na wojnie częścią przedawali do postronnych państw, częścią ucinali ręce, wiecznym kalectwem oznaczając dzikość swojego okrucieństwa ${ }^{42}$.

Reasumując: kanonik jest zdania, że kiedy się będzie rozpatrywać osiemnastowieczną Europę, czy to $\mathrm{w}$ porównaniu $\mathrm{z}$ innymi kontynentami, czy z innymi epokami, może się okazać, iż jeśli chodzi o skłonność do niszczących konfliktów i wyczerpujących zbrojeń, dzierży ona niezbyt zaszczytną palmę pierwszeństwa:

...wiek nasz mówiemy, że oświecony, i Europa nasza najoświeceńsza część świata, przy tym wszystkim obrachować można, czyli w wieku naszym mniej się przelało krwi ludzkiej od przeszłych wieków, czyli są częściej powstające wojny w Azyi,

na ziemiach polskich i uprowadzili do niewoli. Książę litewski Gedymin, wysłuchawszy swatów z wiclką radością, wyraża chętnie zgodę na tego rodzaju związki pokrewieństwa. Zgodnic z postawionymi warunkami przckazując swoją córkę posłom królcwskim, uwalnia wszystkich jeńców polskich: kobiety i mężczyzn, wszclkicgo stanu i pochodzenia, i odsyła do ich siedzib, do Polski" (Roczniki czyli Kroniki sławnego Królestwa Polskiego, tł. J. Mrukówna, ks. IX, Warszawa 1975, s. 162-163). Za Długoszem powtarza informację o sprawie posagu Anny-Aldony Adam Naruszcwicz (zob. Historyja narodu polskiego, t. 5, Warszawa 1803, s. 311, 526).

39 F. S. Jezierski, Rzepicha..., op. cit., s. 229, przyp. (a).

40 Idem, Gowórek herbu Rawicz..., op. cit., s. 161.

${ }^{41}$ „Żaden z "filozofów na tronie», nawet Fryderyk II, nic był tak wysławiany przez francuską "republikç literacką" jak "Semiramida Północy", do której Wolter modlił się słowami: "Te Catharinam laudamus, te dominam confitemum (Ciebie, Katarzyno, chwalimy, ciebie, o pani wyznajemy)", (E. Rostworowski, Historia powszechna. Wiek XVIII, Warszawa 1984, s. 755).

42 F. S. Jezicrski, Tron dla próżnej powagi..., op. cit., s. 119. 
w Afryce, jak w naszej Europie, i czyli która część świata chowa raz na raz do dwóch milionów ludzi, którzy na to są wyznaczeni, aby się uczyli zabijać drugich i aby przełożeństwa krajów straszyli się niemi nawzajem ${ }^{43}$.

\section{Wokół problematyki wojny sprawiedliwej}

Jezierski nie idealizuje wieków średnich. W dokonywanych przezeń - mniej lub bardziej fragmentarycznych - rozbiorach czy to dziejów poszczególnych narodów (w szczególności Polaków), czy rodzaju ludzkiego, na ogół daje się zauważyć zdrową dawkę niezależności i krytycyzmu. Przywołane powyżej wypowiedzi wskazują, iż Jezierski ma na uwadze nie wychwalanie zamierzchłej przeszłości, ale przede wszystkim rozpoznanie i napiętnowanie schorzeń epoki, w której przyszło mu żyć. W Rzepisze... Piast — porte-parole kanonika — w jednym z wystąpień stanowczymi słowy potępia rozbójnicze wojny:

Nie to jest chwałą narodu napadać sąsiedzkie granice, rabować wieśniaków, pędzić w niewolą równo ludzi i bydło, pożogą paląc miasta i włości ${ }^{44}$.

Ksiądz Franciszek Salezy opatruje to zdanie następującym przypisem:

W wiekach gotyckich taki był powszechny sposób wojny, naszego zaś wieku wcale różny — z tym wszystkim równie szkodliwy. W owych wiekach każdego czasu widzieć można było miliony nieszczęśliwych niewolników, w naszych czasach takowe wojska monarchów europejskich są miliony niewolników; pierwsi i drudzy są igrzyskiem dziwackiego okrucieństwa lubo sposobem przeinaczonym ${ }^{45}$.

W dość krótkim, ale bardzo interesującym haśle Wojna z Niektórych wyrazów... Jezierski zastanawia się nad treścią tytułowego terminu ${ }^{46}$ oraz szkicuje godny uwagi, choć cząstkowy podział przemian $^{47}$, jakim przez stulecia ulegały cele i zasady prowadzenia konfliktów zbrojnych. Powiada, iż wojny w zamierzchłych wiekach były związane $\mathrm{z}$ wędrówkami ludów, z częstokroć krwawymi zmaganiami o krainy, terytoria, obszary, na których poszczególne plemiona czy większe ugrupowania etniczne chciały osiąść, nie troszcząc się nadmiernie o zgodę autochtonów ${ }^{48}$. Z kolei

${ }^{43}$ Idem, Niektóre wyrazy..., op. cit., s. 172-173.

44 Idem, Rzepicha..., op. cit., s. 320.

45 Ibidem, przyp. (l).

46 „WOJNA. To jest powstanic narodu przeciw narodowi, albo oburzenic siç władzy zwierzchnicj jednego kraju na drugi. Zaciągi więc żołnicrzy, zgromadzenic wojsk, zastanowienic i poruszenie obozów, utarczki podjazdów, rozcsłanic szpicgów, wydanic bitwy, oblężcnic i dobywanic miast, wszystko to razem biorąc nazywa siç wojną. Samo zaś dzicło morderstwa nazywają walką lub bitwą, dawnicjsi nazywali potrzebą (po dzisicjszemu mówią bataliją)" (F. S. Jezierski, Niektóre wyrazy..., op. cit., s. 261-262).

${ }^{47}$ Kanonik sądzi, żc choć istota człowicka jest dana raz na zawszc, to jednakżc formy społeczne ludzkich zachowań są zależne od wielu czynników. Na sposób wojowania znaczny wpływ wywiera ustrój polityczny i prawny. „Duch wojenny narodów przcinacza siç w swoich sposobach i w swoich zamiarach według odmiany sposobu myślenia, bo lubo ludzka natura nic odmicnia siç, alc rząd nad ludźmi wiclki ma wpływ do przcinaczania ich woli" (ibidem, s. 262).

${ }^{48}$ Myśl o przcpoczwarzeniach wojny wraz z tokiem dzicjów pojawia sį̨ nicjednokrotnic w twórczości kanonika. W innym micjscu tak oto ją wysłowił: „Nic była wojna w owych wickach wzorem i podobieństwem dzisiejszych 
najbardziej typową postacią wojen doby rozdrobnienia feudalnego są — utrzymuje ksiądz Franciszek Salezy — zajazdy, napady i utarczki pomiędzy władcami mniej lub bardziej niepokaźnych państewek. W następnej epoce, trwającej wedle kanonika aż po osiemnaste stulecie, kształt wojen jest określany przez potężniejsze organizmy polityczne, w szczególności przez monarchie narodowe ${ }^{49}$. W przywołanym haśle czytamy:

W późniejszych wiekach, aż do naszego dzisiejszego, państwa europejskie chowają gromadne wojska, gotowym nakładem ich utrzymując, monarchowie coraz w nowe zachodzą umowy, sprzymierzenia, tym związkiem sojuszów jeden drugiego straszy i trwoży, przyciska do zawarcia pokoju albo do podniesienia wojny, celem zaś tej wszystkiej polityki obracającej wojną jest próżność monarchów albo ich ministrów i korzyści handlowne narodów kupieckich ${ }^{50}$.

Jednakże - uważa kanonik - urzeczywistnianie owego celu, zaspokajanie próżności monarchów i ich ministrów, zapewnianie korzyści handlowych narodom kupieckim pociagga za sobą olbrzymie koszta, zarówno ekonomiczne, jak i społeczne:

Z tych przyczyn ma Europa coraz większe wojska, i jak jeden monarcha pomnaża, tak sąsiedzki zaraz to czyni. Lud pracowity podejmuje ciężar utrzymywania tych krwawego rzemiosła bliźnich współziomków ${ }^{51}$.

W aforystycznym zakończeniu hasła autor zręcznie i w iście lakonicznym stylu rekapituluje swoje wywody, a jako puentę przedstawia paradoksalną, lecz — jak zdaje się wskazywać doświadczenie dziejów — prawdziwą tezę, iż pokój w militarystycznym państwie jest dla szeregowych poddanych niewiele lepszy niż wojna:

I jak przenosiny narodów robiły wojny, jak w czasie feudalnych rządów napadania, pożogi i rabunki uciemiężali wojną, tak dziś przygotowania do wojny, utrzymywanie wojsk gotowych niezmiernym nakładem wyrabia skutki wojny ${ }^{52}$.

Na podział wojen można spojrzeć również z ogólniejszego, w pewnym sensie ponadhistorycznego punktu widzenia $-\mathrm{z}$ punktu widzenia moralności. Banalna na pozór konstatacja z Niektórych wyrazów..., iż "Wojna dąży do obrony własnego kraju lub do zawojowania cudzego" "53, jest napomknieniem, które może być odniesione do jednej z bardzo ważnych i długotrwałych debat $\mathrm{w}$ dziejach umysłowości europejskiej. Przedmiot owej debaty — aktualnej także i w dniu

wojen; były to wyraźne przenosiny narodów, cały naród następował na drugi, każdy miał napcłnione serce własną wolą i chętnie tęż samą ziemię skrapiał krwią swoją, którą gwałtownic chciał mieć ojczyzną dla sicbie" (F. S. Jezierski, Rzepicha..., op. cit., s. 25).

49 „W teraźniejszych zaś wiekach wojna, ile zawicra samę sztukę zabójstwa wzajemnego, zowic siç taktyką, a ile jest zamysłem przełożonego narodu i umową sprzymicrzeń, zowie się polityką" (ibidem).

50 F. S. Jezierski, Niektóre wyrazy..., op. cit., s. 263.

51 Ibidem.

52 Ibidem.

${ }^{53}$ Ibidem, s. 262. 
dzisiejszym — to, w istocie rzeczy, pytanie o sens przeciwstawnych terminów „wojna sprawiedliwa" i „wojna niesprawiedliwa”.

W teologii i filozofii chrześcijańskiej kwestia ta była po raz pierwszy rozpatrywana w sposób bardziej dogłębny przez św. Augustyna. Biskup Hippony powoływał się na poglądy zawarte w pismach Cycerona:

Wiadomo mi, że w dziele O państwie, w trzeciej — jeżeli się nie mylę — księdze mówi Cycero, iz państwo najlepsze podejmuje wojny jedynie dla dochowania wierności lub dla własnego ratunku ${ }^{54}$.

Teza, że wojna obronna przeciwko niczym niesprowokowanej agresji jest sprawiedliwa, nie podlega w zasadzie poważniejszym wątpliwościom. Prawo do skutecznej obrony — nawet jeśli ma ona doprowadzić do śmierci krzywdziciela czy krzywdzicieli — jest prawem naturalnym, przysługującym zarówno jednostkom, jak i społecznościom:

Przecież bardziej odpowiada poczuciu humanitarności, żeby ginął napastnik, a nie ten, kto broni swego życia. I większą grozą przejmuje fakt, że człowiek przemocą zostaje zhańbiony, niż że gwałciciel traci życie z ręki swej niedoszłej ofiary ${ }^{55}$.

W przypadku wojny zaczepnej rzecz staje się bardziej skomplikowana. Czy istnieją jakiekolwiek okoliczności zdolne sprawić, iż wojna zaczepna będzie sprawiedliwa? Augustyn twierdzi, że tak. W słynnym wywodzie z Problemów Heptateuchu powiada:

Zwykło się zaś określać wojny jako słuszne te, które są odwetem za krzywdy, jeżeli jakiś naród albo też państwo, które drogą wojny należy zdobyć, albo zaniedbało ukarać niesprawiedliwe postępki swoich [obywateli], albo też zwrócić to, co droga krzywdy zostało zagarnięte. Ale bez wątpienia i taki rodzaj wojny jest sprawiedliwy, który nakazuje Bóg, u którego nie ma nieprawości i który wie, co się każdemu należy. W takiej wojnie dowódca wojsk albo też sam lud nie tyle powinien zostać uznany za jej sprawcę, co za ministra ${ }^{56}$.

Biskupa Hippony koncepcja sprawiedliwej wojny zaczepnej bywała i bywa kwestionowana ${ }^{57}$. Jedną rzecz wszakże trzeba klarownie naświetlić. Koncepcja ta nie może być w pełni zrozumiana

\footnotetext{
54 Św. Augustyn, O państwie Bożym przeciw poganom ksiug XXII, tł. W. Kornatowski, t. 2, Warszawa 1977, s. 562, por. Cycero, Rep. 3, 23, 34.

s5 Idem, O wolnej woli, th. A. Trombala, w: idem, Dialogi filozoficzne, Kraków 1999, s. 502.

${ }^{56}$ Por. idem, Problemy Heptateuchu, tł. J. Sulowski, cz. 2, Warszawa 1990, s. 64.

${ }^{57}$ Przykład z ostatnich lat — Georges Minois w książcc Kościót i wojna. Od czasów Biblii do ery atomowej (tt. A. Szymanowski, Warszawa 1998) utrzymuje, iż zarówno doktryna wojny sprawied liwej sformułowana przez autora Państwa Bożego..., jak i doktryny z niej się wywodzące (także dwudziestowieczne) są jałowe: „Dla świętego Augustyna wojnę sprawiedliwą prowadzi Rzym, który broni cywilizacji i chrzcścijaństwa przeciwko tym okropnym barbarzyńcom niosącym grabież i zniszczenie. Jaki sens może micć w tym kontekścic pojęcic wojny? Od początku wicku rozmaici uzurpatorzy i pretendenci wykorzystują ludy germańskie i azjatyckic jedne przeciw drugim, żcby zaspokoić swoje osobiste ambicje i narzucić swoją władzę schyłkowemu i upodlonemu cesarstwu. Dzisiaj żaden poważny historyk nic zaryzykowałby przyznania racji «Rzymianom» zamiast «barbarzyńcom». To, że samego świętego Augustyna zło-
} 
w oderwaniu od Augustyńskiego nauczania o pokoju. Myśliciel afrykański jest nieumiarkowanym chwalcą pokoju. Wedle niego pokój należy do najcenniejszych wartości zarówno wiecznych, jak i doczesnych. Doskonały jest zapewniający szczęśliwość wieczny pokój Boży w niebie. Ale jeśli tylko i doczesny pokój ziemski opiera się na sprawiedliwości ${ }^{58}$, jest godzien najwyższego uznania:

Przecież dobro pokoju jest tak wielkie, że nawet pośród spraw ziemskich i przemijających zazwyczaj nie możemy o niczym innym słuchać z większą przyjemnością, niczego innego pożądać z gorętszym upragnieniem, nic wreszcie znaleźć lepszego 59 .

Sprawiedliwa wojna, zaczepna bądź obronna, jest dla rozsądnych i dzielnych moralnie ludzi gorzką koniecznością, a stanem upragnionym — pokój:

Lecz mędrzec — powiadają — będzie wiódł tylko sprawiedliwe wojny. — Jak gdyby, jeżeli pamięta, że jest człowiekiem, znacznie więcej nie bolał on nad samą koniecznością staczania sprawiedliwych wojen! Gdyby przecież nie były sprawiedliwe, to by nie musiał ich prowadzić, przez co dla mędrca nie byłoby wojen wcale ${ }^{60}$.

Kanonikowi Jezierskiemu myśl wielkiego Afrykańczyka nie była obca. Wedle świadectwa Kołłątaja, duży wpływ na wykształcenie intelektualne przyszłego autora Niektórych wyrazów... wywarł czas studiów w seminarium Zgromadzenia Misjonarzy św. Wincentego a Paulo:

Autor nasz przejść musiał wprzód przez pasmo omyłek, nim dostrzegł, którą mu drogę na cały ciąg życia ${ }^{61}$ przeznaczyła Opatrzność; (...) przyjmuje na siebie obowiązek powołania duchownego, a zgromadzenie misyjonarzów obiera za szkołę, w której miał nabyć prawideł wysokich cnót i rzadkich przymiotów. W tym

żoność sytuacji zwiodła do tego stopnia, żc uznawał za sprawicdliwą sprawç wiclce dyskusyjną, potwicrdza tylko jałowość tcorii wojny sprawiedliwcj. Tcolodzy, idąc za świętym Augustynem, będą przez wiele wicków powiększać nadarcmnic stos woluminów, próbując sformułować najdoskonalszą definicję wojny sprawicdliwcj” (s. 69).

Nic ma tu miejsca na pobieżne nawet przedyskutowanic stwierdzcń Minois. Zauważmy tylko, że w całcj swcj książce nie poświęca należytej uwagi zagadnieniu prawowitości wojny czysto obronncj. Kiedy Minois wygłasza zdecydowany pogląd, że „Wojna jest złcm. Nadal istnicjc, ale prawo do nicj stało sic̨ przcżytkicm" (s. 464), warto ową tezç skonfrontować ze stanowiskiem Johna Rawlsa, tak oto wyrażonym w jego Prawie ludów (tł. M. Kozłowski, Warszawa 2001): „Zapewne wojna jest swego rodzaju pickłem, dlaczego jednak znaczyć ma to, że wszystkic normatywne rozróżnienia tracą moc? Można przyjąć, że czasem wszyscy lub prawie wszyscy są w jakimś stopniu winni; nie znaczy to jednak, że wszyscy w równym stopniu. Mówiąc krótko, nigdy nic jesteśmy zwolnieni od dokonywania zniuansowanych rozróżnień zasad moralnych i politycznych oraz od stopniowania ograniczeń” (s. 150).

${ }^{58}$ Jeśli ludzie źli i niesprawiedliwi chcą skutecznie osiagać wspólnic upatrzone cele, muszą miçdzy sobą żyć przynajmniej w jakiej takicj zgodzie. Pisarz afrykański zauważa, iż „nawct rozbójnicy, by tym skutecznicj i bezpiccznicj napastować pokój innych, pragną go zachować w stosunkach zc swoimi współtowarzyszami” (O państwie Bożym..., op. cit., s. 412). Pokój zaprowadzony przez złoczyńców jest, rzecz jasna, wynaturzenicm sprawiedliwego pokoju, w istocie rzeczy - jego przeciwieństwem: „człowiek, który umie przedkładać prawość nad nikczemność, a ład nad nieład, pojmuje, iz pokój niesprawiedliwych w porównaniu z pokojem sprawiedliwych nic zasługuje nawet na nazwę pokoju" (ibidem, s. 414).

${ }^{59}$ Ibidem, s. 411.

${ }^{60}$ Ibidem, s. 407.

${ }^{61}$ O niektórych problemach tyczących się biografii księdza Franciszka Salczego napomykam we wzmiankowancj powyżej publikacji Kaznodzieja i prześmiewca. Uwagi o niektórych zagadnieniach twórczości i życia Franciszka Salezego Jezierskiego. 
zgromadzeniu, któremu duchowieństwo nasze po większej części winno jest oświecenie, formuje się na człowieka i kapłana dobrego. Nauki duchowne składając szkołę misyjonarzów, stały się mocnym fundamentem i prawidłem wszystkich wiadomości, których w ciągu swego życia nabył; w teologiji i historyi kościelnej biegły, uformował się na bardzo dobrego kaznodzieję ${ }^{62}$.

Trudno sobie wyobrazić nawet elementarny kurs teologii (i filozofii) prowadzony w seminarium misjonarzy, w którym nie odwoływano by się do nauczania autora Państwa Bożego.

W Pamiętniku o stanie Kościota polskiego katolickiego i o wszystkich innych wyznaniach w Polszcze powiada Kołłątaj:

Nauki potrzebne do stanu duchownego - te po seminaryjach dawano. Kleryk przychodzący powinien był umieć po łacinie, bo wszystkich lekcyi w tym się języku uczyć musiał, jako to: logiki, metafizyki, teologii moralnej i sakramentalnej; w niektórych seminaryjach misyjonarskich była teologia dogmatyczna i historyja kościelna, ale mało kleryków miało czas odbyć te kursa. Teologia dawana była podług nauczycielów; jezuici na przykład dawali ją w swych przepisach podług Moliny i Busenbauma; misyjonarze nadstawiali się św. Augustynem, chronili się jednak wprowadzać takich kwestyi, które molinistów z jansenistami kłóciły ${ }^{63}$.

Z kolei dzisiejszy historyk Kościoła pisze (w odniesieniu do baroku i oświecenia):

Misjonarze również prowadzili w tym czasie studium filozofii dla tych alumnów, którzy przychodzili do seminarium bez wykształcenia filozoficznego. Wstępna i pobieżna analiza materiału rękopiśmiennego oraz starodruków wskazuje na zainteresowanie u misjonarzy tymi zagadnieniami w filozofii, które mają bezpośrednio przygotować do dalszego studium teologii. (...) Logikę traktuje się za Arystotelesem wyłącznie jako narzędzie do poznania rzeczywistości, a za św. Augustynem upatruje się w niej wartości formacyjne dla tych, którzy zajmują się wiedzą ${ }^{64}$.

Ksiądz Franciszek Salezy potrafi umiejętnie — w sposób wykraczający poza czysto ozdobną, retoryczną cytację, a sięgający sedna sprawy — odwołać się do myśli etycznej i politycznej pisarza afrykańskiego. W jednym ze swych wystąpień - które poświęcone jest powinnościom dobrego sędziego, a także potępieniu lekceważenia czy anarchizowania prawa - każe takimi oto słowy:

Sprawiedliwość była zawsze i będzie grunte[m] utrzymywania społeczeństwa w pożyciu ludzkiem na ziemi, i jej powagą stoją narody, i gdy jej zabraknie królestwa na ów czas, powieda św. Augustyn, zamieniają się w publiczne łotrostwa ${ }^{65}$.

${ }^{62}$ H. Kołłątaj, Przedmowa, w: F. S. Jezicrski, Niektóre u'yrazy..., op. cit., Warszawa 1791, s. X.

${ }^{63}$ H. Koltątaj, Pamiętnik o stanie Kościoła..., w: idem, Stan ośuiecenia w Polsce w ostatnich latach panowania Augusta III (1750-1764), opr. J. Hulewicz, Wrocław 1953 (BN I 144), s. 206.

${ }^{64}$ J. Dukała, Szkoła księży misjonarzy, w: Dzieje teologii katolickiej w Polsce, red. M. Rechowicz, t. 2, cz. 2, Lublin 1975, s. $155-156$.

${ }^{65}$ F. S. Jezierski, Kazanie przy zaczęciu Trybunatu Koronnego ma prowincyja małopolska poczynajacego się dnia 19 kuvietnia 1784 
Kanonik nawiązuje tu do rozważań biskupa Hippony z rozdziału czwartego, czwartej księgi Państwa Bożego:

Czymże są więc wyzute ze sprawiedliwości państwa, jeśli nie wielkimi bandami rozbójników? Bo czyż i rozbójnicze bandy są czymś innym niż małymi państwami? Wszak i banda jest gromadą ludzi rządzących się rozkazami swego przywódcy, związaną przez ugodę o wspólności i rozdzielającą zdobycz wedle przyjętego przez się prawa ${ }^{66}$.

Myślę, iż nie przebiorę miary, gdy powiem, że z pozycji obserwatora, mającego za sobą wiek dwudziesty, i sam tekst Augustyna, i parafraza Jezierskiego nie tylko się nawet o jotę nie zdezaktualizowały, ale nabrały jakby proroczych rysów ${ }^{67}$.

W wypowiedzianej przez Jezierskiego w haśle Pokój z Niektórych wyrazów... sentencji, iż „Pokój między narodami jest ich prawdziwym szczęściem"68 — niezależnie od tła oświeceniowych dyskusji, toczonych na ów temat w Europie i również w Polsce ${ }^{69}$ — pobrzmiewają echa augustynizmu.

Wyrażający poglądy kanonika w Rzepisze... Piast stwierdza, iż

...do sprawowania kraju z pożytkiem mieszkańców, trzeba w pokoju, jedności i w zgodzie obierać korzyści, i te są tylko prawdziwe zasady chwały panujących. Niech będą serca rycerstwa składem dzielności i męstwa, zażyciem zaś tego powinna zarządzać sama potrzeba obrony krajowej ${ }^{70}$.

Jedynie wojna obronna jest dopuszczalna ${ }^{71}$ i tylko ona zasługuje na miano wojny sprawiedliwej. Ksiądz Franciszek Salezy troszczy się w Rzepisze..., by swą koncepcję wojny sprawiedliwej przedstawić możliwie przystępnie. Wykorzystując możliwości dawane przez literaturę, opisuje fikcyjną wojnę między starożytnymi Prusami a Polakami pod wodzą Piasta i jego syna Semowita.

w Lublinie..., cyt. za: idem, Dwa wystapienia trybunalskie, opr. B. Treger, „Napis”, scria V, 1999, s. 92.

${ }^{66}$ Św. Augustyn, O państwie Bożym..., op. cit., t. 1, Warszawa 1977, s. 223.

${ }^{67}$ Koncepcje filozoficzne i społeczne Afrykańczyka mają niejednokrotnic prckursorski charakter (przykładowo: formuła dubito ergo sum analogiczna do Kartezjuszowcj; analiza czasu podjęta później przez Husscrla). O nowatorstwie jego rozważań w kwestiach wojny i pokoju pisze Wiktor Kornatowski: „Jak słusznie zwraca się uwag̨̨, wiele przytoczonych w związku z zagadnieniem pokoju i wojny postulatów Augustyna miało wielkie znaczenie dla rozwoju prawa międzynarodowego. Nie nastąpiło to jednak w starożytności. Swiat starożytny bowicm nigdy nie przezwyciężył poglądu, że państwo jest tylko sumąjego obywateli, i nie zdołał uświadomić sobie, że prawo miçdzynarodowe krępuje w pierwszym rzędzie państwa jako takie. Toteż idee Augustyna znalazły uznanie i rozpowszechnienic dopiero w przyszłości" (Społeczno-polityczna myst św. Augustyna, Warszawa 1965, s. 196).

${ }^{68}$ F. S. Jezierski, Niektóre wyrazy..., op. cit., s. 172.

${ }^{69}$ Dobrym wprowadzeniem do tematyki projektów wieczystego pokoju w Europie i Polsce XVIII wicku jest artykuł Mariana Skrzypka, Abbé de Saint-Pierre, Rousseau, Skrzetuski et leurs projets de paix perpétuelle, w: Le siècle de Rousseau et sa postérité. Mélanges offerts à Ewa Rzadkowska, wyd. I. Zatorska, A. Sicmek, Warszawa 1998, s. 167-174.

${ }^{70}$ F. S. Jezierski, Rzepicha..., op. cit., s. 320.

${ }^{71}$ W tym miejscu można znów poczynić uwage o dobrej intuicji kanonika. W jedncj z najgłośniejszych ostatnio koncepcji wojny sprawiedliwej punktem archimedesowym jest również wojna obronna: „Zadne państwo nie ma prawa do wojny jako realizacji swego racjonalnego interesu. Prawo ludów nadaje jednak wszystkim ludom dobrze urządzonym (zarówno przyzwoitym, jak i liberalnym) oraz, w istocic, każdemu społeczeństwu, które przestrzega rozsądnie sprawiedliwego prawa ludów i honoruje je, prawo do wojny obronnej” (J. Rawls, Prawo ludów, op. cit., s. 133). 
Przy czym Piast i Semowit - nie zepsuci jeszcze kulturą dworską - w polityce wojennej kierują się nie samowładczą racją stanu, ale sprawiedliwością i humanitaryzmem. Piast wysyła syna na wojnę dopiero wtedy, gdy Prusowie zdradziecko odrzucają wszelkie propozycje pokojowej ugody i szykują kolejną napaść na państwo Słowian. Cel wojny prowadzonej przez gnieźnieńskiego księcia to ustanowienie zgody i przyjaźni między sąsiedzkimi ludami.

Kampania prowadzona przez Piastowicza to modelowy przykład (niemalze typ idealny) wojny sprawiedliwej. Po zwycięstwie młody władca nie tylko nie ciemięży pokonanych, lecz traktuje z godną podziwu wielkodusznością:

Książę Semowit zgromadziwszy i pierwszych panów swego narodu, i mając przytomnych w niewoli z książęciem Prutenów jego kraju urzędników, powiedział obszernym wywodem, że lubo szczęście wojny zrobiło go zwycięzcą ich, jednakże nie myśli być ani ich panem, ani nie żąda żadnego hołdu $z$ ich majątku:

- Ja przyszedłem z wojną do waszej ziemi, żeście mi w mojej nie dali pokoju, i rabowaliście moich poddanych, zażądaliście Pomorza dlatego, że waszym granicom przyległa ta prowincyja, chociaż zaś wasza ziemia także jest bliska moim państwom, ale że nie jest moja, ja prawem zwycięstwa nie chcę jej nabywać, ponieważ to nie było miło ani mnie, ani mojemu ludowi, żeście mi moją własność wydzierali. Powiadacie mi, że chcecie hołd dawać ${ }^{72}$, ja chcę miasto hołdu sprawiedliwości, abyście byli między sobą zgodni i spokojni, abyście zachowali karę na występki, nadgrodę za zasługi w waszym rządzie. Trzymajcie słuszność w sądach i nie kłóćcie się z narodami pogranicznemi, a gdy się przytrafią jakie niesnaski, nie [wolno wam] zaraz się miotać do zaborów i łupiestwa na sąsiadów; pilnujcie rolnictwa i kupiectwa, niech będą drogi u was bezpieczne do przejazdu. Otóż to zachowajcie dla siebie, miasto hołdu, co mi przyrzekacie. Nie mam ja tej chciwości, abym granice mojej ziemi rozszerzal, mam jej dosyć, byle była osiadła i urządzona. Nie najwięcej te narody wskórały, które chciały cały świat połknąć — i wy miejcie swoje, a ja na moim przestanę.

To powiedziawszy uwolnił wszystkich więźniów, książęcia Pomezo udarował, a rozkazawszy opuścić zamki i osady pobrane w ziemi Prutenów, ruszył z obozami na powrót do Słowiańszczyzny ${ }^{73}$.

Piastowicz przedstawia ideał sprawiedliwego władcy, który przekłada wartości etyczne (cnoty moralne) nad osobiste ambicje:

Książę Semowit powróciwszy ludowi swojemu spokojność i zabezpieczywszy się w niej na potym, korzystał w słodyczy umysłu z ukontentowania takiego, jakiego tylko doświadczyć mogą cnotliwi rządcy narodu. Nie zbroczył rąk swoich krwią nieprzyjaciół, tylko ile wyciągała nieszczęśliwa potrzeba wojny odpornej. Nie uniósł się chci-

${ }^{72}$ W 2 . wyd. Rzepichy..., (Warszawa 1794, s. 284) jest: „, hołdować”.
${ }^{73}$ F. S. Jezierski, Rzepicha..., op. cit., s. 393-395. 
wością zdobyczy, aby nie dał światu niesłuszności przykładu, a zatym przeświadczenia wewnętrzne o tym wystarczyły mu za wszystkie podchlebstwa, których przepuszczająca Opatrzność nie broni dla panujących osób ${ }^{74}$.

Wróćmy do świata realnego. Tu o wiele trudniej niż w literaturze ferować oceny — także moralne ${ }^{75}$. Nie znaczy to jednak, iż koncepcja wojny sprawiedliwej nie może być wzorcem, do którego przyrównuje się - lepiej lub gorzej — rzeczywiste wydarzenia historyczne:

Ogłoszona ta wojna wprowadziła króla Jana i naród nasz polski w sprzymierzenie $z$ Leopoldem cesarzem na obronę domu jego i państwa ${ }^{76}$.

Bicie $\mathrm{z}$ harmat wzajemne z obojej strony zaczynało dzieło następującego dnia — ten był 12 września, od którego zawisło, czyli Wiedeń miał być pod Mahometem IV, tak jak Carogród pod Mahometem II, i czyli państwo zachodnie miało się złączyć ze wschodnim, i na koniec czyli Europa miała być chrześcijańską albo nie ${ }^{77}$.

${ }^{74}$ Ibidem, s. 397-398.

${ }^{75}$ Cytowany tu już John Rawls powiada, że „Odpowicdzialność za wojnç rzadko spada na jedną tylko stronç. Jcst ona jednak stopniowalna. Dlatego zapewne słusznic będzie zauważyć, że jedna strona może ponosić odpowicdzialność większą niż druga. Inaczcj mówiąc: nicktóre ręce są brudniejsze od innych" (idem, Prawo ludów, op. cit., s. 139). ${ }^{76}$ F. S. Jezierski, Mowa przy obchodzeniu pamiątki stu lat zuycięstwa pod Wiedniem Jana III miana w Lublinie przez...; zob. w ninicjszym tomic s. 365 .

${ }^{77} \mathrm{~W}$ niniejszym tomic s. 366. 


\title{
Franciszek Salezy Jezierski
}

\section{Mowa przy obchodzeniu pamiątki stu lat zwycięstwa pod Wiedniem Jana III miana w Lublinie}

\author{
Opracował Bronisław Treger
}

Najjaśniejszy Trybunale! ${ }^{1}$

Ponieważ wiek, sto razy obróciwszy rokiem, już skończył się ten, w którym wielkiego przedsięwzięcia dziełem Jan III, narodu naszego król, Wiedeń miasto stołeczne państw Austryi od oblężenia zastępnych wojsk tureckich uwolnił, zwycięstwo, tak okazałym męstwem zjednane, nie tylko zminąć się nie może z pamięcią, ale owszem wystawia w umysłach naszych powinność, abyśmy nad tym zastanowili uwagę, czego dopełniemy dzisiejszym uroczystym obchodem.

Chwała Polaka króla i chwała narodu polskiego zostaje potomności dziedzictwem, a jeżeli w historyi obcych narodów wielkie dzieła zadziwiają rozum, gdy ich pamięć w istotnym wyobrażeniu wspomina, dzieła własnego narodu prócz zdumiewania rozumu i ozdobienia wiadomością pamięci mają coś tak mocnego w sobie, co jeszcze i serce porusza. Sława wielkich mężów jest głosem cnoty, tak jak brzęk monety jest głosem kruszcu, z którego jest zrobiona, a równo pierwsze, jak i drugie musi być miarą szacunku. My, następcy poprzedników naszych, mamy prawo naturalne uczucia cząstki radości z ich wielkiego sprawowania się. Niech następne plemię młodzieży narodowej korzysta wspomnieniem sławy mimo ucisk dotykających Ojczyznę przykrości. Gdy więc mi przynależy z obowiązku stanu mojego akademickiego wspominać sławę i króla,

\footnotetext{
${ }^{1}$ Okazją wystąpicnia była sesja Trybunału Koronncgo dla prowincji małopolskicj — por. F. S. Jezierski, Dua u'ystapienia trybunalskie, opr. B. Treger, "Napis”, scria V, 1999, s. 87-94.
} 
i narodu zwycięskiego na ów czas, to mam zdarzeniem łaskawego szczęścia, że mówić zaczynam w przytomności Najjaśn[iejszego] Trybunału, Najwyższego w Królestwie Sądu; przeświadczam się albowiem, że w oczach mężów składających zgromadzenie sprawiedliwości prawda ma być szczególnym widokiem i zamiarem, przeto mówienie moje tej prostej będzie wyobrażeniem prawdy.

Polskiego narodu król Jan III Sobieski Turków zwyciężył i Wiedeń stolicę państw Austryi od oblężenia uwolnit. Ta prawda przez usta moje niech oddaje chwałę zimnym prochom wielkiego króla, niech odnawia pamiątkę sławy i niech ją oddaje następującej potomności, a mnie do dalszego mówienia podając okazyją, w taki sposób przedzieli uwagę, jaki jest stan narodu polskiego, w którym królował Jan III, i jakie były przymioty królującego Jana III. Istota i postać narodu każdego składa się z wychowania młodzieży, sposobu myślenia obywatelów, z rządu krajowego i na koniec ze skutków pochodzących $z$ tego wszystkiego razem, tak jak drzewo składa się z korzenia, z pnia, z gałęzi, a na koniec z kwiatu i owocu swojego. Te trzy własności są charakterem narodów, te różnicę jednych od drugich czynią.

Co to zaś jest wychowanie młodzieży, lubo odpowiedź na to niemało uczonych rozum zatrudnia, jednakże ja bym sądził, że to jest to wszystko, co przez zmysły wstępuje na umysł jako przez bramy duszy w poranku dzieciństwa, wszystko, co się widzi, słyszy, czego się dotyka, to się pojmuje, czuje, poznaje i doświadcza, do tego przywiązuje się rozum i to sobie obiera wola. Taką drogą wychowania nabywamy prawdy i nieprawdy, przesądu i uprzedzenia lub też prawdziwego dochodzenia rzeczy. Za tym idzie położenie zdania w dalszym życiu, i samo nawet obrócenie się skłonności naszych na tym zawisło.

Sposób myślenia obywatelów jest przeciąg tego samego, co było wychowaniem w ich młodości, tylko że już wsparte zostaje doświadczeniem, upoważnione przykładem prawdy albo przesądu, każda też ćwierć życia ludzkiego osobnych namiętności posiada żądze.

Rząd w narodach wolny albo niewolny przytrafia się z przypadków i wydarzonych okoliczności, wychowanie jednak młodzieży i sposób myślenia obywatelów mają niemałą cząstkę w przyłożeniu się do tego. Cnota, pożytek, chwała, i co tylko może być uszczęśliwieniem narodów, wynika $z$ tego wszystkiego razem, według miary przyczyn wyrabiając skutki.

Chociaż posunę myśl, przedzierając się pamięcią przez odległość wieków aż do samej kolebki Polski i pierwiastkowych Polaków, wychowania ich młodzieży nie potrafię sobie wystawić istotnie; tego zaś sprawiedliwie domyślać się należy, że naród żyjący w prostocie obyczajów, dzielący prace swoje między czas pokoju i wojny miał wychowanie surowe, tak jako i obyczaje ostre, obchodząc się potrzebami życia nie tylko bez zbytku, ale nawet podobno bez wygody. Męstwo dzikie i razem odważne dało im osady ziemi między Odrą, Wartą i Wisłą zawsze bez podległości Rzymianom, a potym ramię zręczne i serce śmiałe posuwało granic narodu aż do naszego dzisiaj najokropniejszego stanu i czasu.

Wiadomość początkowej historyi przybrana w fantazyją autorów, w dzieła niepewne, zaćmiła prawdę. Ten błąd powszechnie wszystkich krajów napełniał pierwiastkowe kroniki, naśladowanie podobno zabrawszy wzorem historyi Greków. W bliższych nam wiekach Bolesław Chrobry $\mathrm{z}$ familiji Piasta pokazuje się w historyi pod wyraźną postacią prawdy i chwały, król mężny, 
szczęśliwy, przezorny. Czemuż po nim zaraz nie było drugiego takiego dla Polski? Już w wieku dziesiątym religija prawdziwa zaczęła być prawidłem i poświęceniem cnoty Polaków, weszły z nią nauki takie, jakie naówczas Europa miała, to jest sprowadzaniem i osadzaniem mnichów.

Rząd kraju jednowładny zostawał w ręku siedzącego na tronie. W każdym rodzaju rządu są wady; wieku owego ta była, że monarchowie dzielili kraje między potomstwo, źrzódło zostawując następującym wiekom wojny wewnętrznej, a nigdy niezdolnej do oparcia się postronnej. Lecz ten przesąd był przesądem wieków i zwyczajem narodów szkodliwym. Namnożoną liczbę książąt udzielnych we Francyi przepleniły krucjatów wyprawy, w naszej zaś Polszcze sam tylko przeciąg czasu tego dokazał, i już w czternastym wieku Kazimierz Wielki sam panował nad całym krajem oprócz Mazowsza, bo to miało jeszcze swych książąt. Kazimierz był prawdziwie królem wielkim; dał Polszcze prawa pisane dla dochodzenia sprawiedliwości; ażeby naród oświecić, sprowadziwszy nauczycielów z obcych akademiji, założył Szkołę Królestwa w Krakowie; dał mury dla obrony miast; pomnożył rolnictwo; przyłączył Ruś południową dla rozszerzenia kraju. Ten monarcha śmiercią swoją skończył familiją Piasta i przerwał zaczęte przez siebie uszczęśliwienie narodu.

Przy wstępie familiji Jagiełłów na tron zaczęła wschodzić i pokazywać się wolność, nie mówię wolność narodu, bo tej nigdy nie było, ale tylko wolność stanu szlacheckiego w narodzie. Jagiełły następcy, mając dziedziczną Litwę, nadawali mnóstwo przywilejów szlacheckiemu stanowi z ujmą własności tronu. Po zeszłej liniji męskiej tego domu linija Wazów już zastała Polski i Litwy szlachtę rządzącą w narodzie. Wszedł duch wolności, imię R[zeczy]p[ospo]l[i] tej powstało, a zgasła linia domu panującego otworzyła porę wolnego obierania królów, którym dany majestat i szafunek rozdawania stanowi rycerskiemu wszystkiego. Dobra królów poszły w ręce prywatnych pod imieniem starostw, a zamki i twierdze kraju w ruinę. Stan rolniczy przywiązany do roli poddany jest panom, bez innego prawa prócz ich woli. Stanowi miejskiemu dostał się zbiór dziwackich gockiego wieku praw pod imieniem saksonu ${ }^{2}$; z tego stanu, co ma być źrzódłem bogactw przez rękodzieła i kupiectwo, pogarda, niedostatek bezpieczeństwa, na koniec nałogi pijaństwa już dawno wypleniły Polskę, motłoch żydostwa ich miejsce zastąpit. Pominąwszy więc wolnośćstan rolników, stan mieszczan, w troistym jednakstanie chciała się pokazać: majestatu, senatu i rycerstwa ${ }^{3}$.

Nic się tedy zacniejszego na całym świecie pojąć nie może po królach i panujących osobach, jak dostojność szlachcica polskiego, ale też nic nie może być szkodliwszego narodowi nad ten zbytek wolności jednego stanu nad insze równie potrzebne i w społeczeństwie życia, i w obywatelstwa związku. Panowie moi, jeżeli powiedzieć można prawdę w tej otwartości, którą świętość jej mieć powinna w duszach wspaniałych: gdy stan rycerski panować zaczął, wojować prze-

2 „Sakson (...) prawo ziemskic saskic (...) der Sachsenspiegel, das Sächsische Recht. Sakson lub prawo chcłmińskic niczym się nie różni od magdeburskiego, tylko przydaniem nowych wolności” (S. B. Linde, Stounik jęzүka polskiego, t. 5, Lwów 1859, s. 29).

${ }^{3}$ Myśl tę rozwinie kanonik w Katechizmie o tajemnicach rzq̨du polskiego: „Pytanie: Kto trzyma władzę prawodawczą i wykonawczą w Rzeczypospolitcj? Odpowiedź: Król, senat i rycerstwo, trzy stany, a jeden szlachcic. P. Więc te wszystkie trzy stany są tylko jednym stanem? O. To jest tajemnica nigdy nie pojęta rozumem, że Rzeczpospolita nic mając, tylko jeden stan szlachecki do swojego rządu, przecież z tego stanu zrobiła trzy stany tak cudownym sposobem, jako i to, że z jednej króla pojedyńczej osoby ma także jeden stan zupełny” (cyt. za: F. S. Jezicrski, Wibór pism, opr. Z. Skwarczyński, wst. J. Ziomck, Warszawa 1952, s. 67). 
stał. Na przystawienie dowodów w tej mierze dosyć powiedzieć, że po zaczętej wolności piędzi Polski nie przybyło więcej; mało na tym, ale wszystkie rządu osłabione zostały sprężyny. Zbytnia wolność nie może mieć przyjaźni z powinnościami, a w przeświadczeniu się o niekarności zbytek i łakomstwo, podawszy sobie wzajem ręce na zepsucie serc, prowadzą narody do zguby. Równość zacnego urodzenia usprawiedliwia chciwość wyrównywania każdemu we wszystkim; gdy się to łączy z skazitelnością serca otrutego miłością własną, podłość uzbraja się przesądem, obowiązki względem Ojczyzny nikną, a wolność zasobna w swoją powagę pomaga pokrywać albo i popełniać występki. Rząd powszechny kraju słabieć musi w takim sposobie myślenia obywatelów. Każdy ziemianin zostaje panem w swych majętnościach i dostatkach, a to, co ma składać rząd powszechny, w nędznej pokazuje się postaci. Skarb bez dochodów, kraj bez wojska i bez obrony, sejmy i sejmiki miejscem zatrudnienia namiętności, nie zaś obrady, sprawiedliwość brzęczy szalami pieniactwa, nie mając w ręku miecza - te to są skutki źle ułożonej i niedobrze zażytej wolności. My poglądamy na czasy przeszłe jak na szczęśliwe, a to owszem czasy były Ojczyzny naszej letargu, po którym nastąpiły konwulsyje. Jeżeli to wyobrażenie stanu Polski naszej wydaje się okropne, a przez moje wyrazy porusza przykre uczucie w sercu czyim, to jest to skutek prawdy, która tyle sprawuje, co czyni ręka lekarza dotykająca miejsce urażające na ciele. Nie w tak powszechnym skażeniu ducha obywatelskiego, lecz przy owej jeszcze w sercach ostrych staropolskiej cnocie i męstwie - Jan III Sobieski, król i bohatyr narodu naszego, ozdabiał się chwałą zwycięstw z nieprzyjaciół ojczyzny i wiary, o którym mówić zaczynam ${ }^{4}$.

Za panowania Zygmunta III w Polsce, za czasów Ludwika XIII we Francyi, nieszczęśliwego Karola I w Anglii, sławnego Gustawa Adolfa w Szwecyi, w roku 1629 urodził się Jan Sobieski w miasteczku Olesku na Rusi, z ojca i z matki szlachetnych domów. Zacna krew płynęła kanałem wieków, której początkowe źrzódło niedostępne jest pamięci, dla odległych dawności czasów. Z obydwu domów, ojczystego i macierzystego, nie zbywało na przykładach męstwa, przezorności,

\footnotetext{
${ }^{4}$ Gdy nic krępowała go konwencja panegiryku, Jezierski wypowiadał bardzicj zróżnicowane sądy o Janic III: „Zgromadzono szlachtę na obranie króla, poludniły osoby wojskowe, ujçte przychylnością swojego wodza, i zwycięstwo świeżo otrzymane torowało mu drogę do tronu, że z latwością mógł zostać królem od narodu wybranym. Kończył on powinności wodza pierwej niźli przystąpił do obrządków koronowania się na króla, zawszc na czcle małego wojska zrażal zastępy nieprzyjaciół, w znoszeniu niewygody, w niebezpieczeństwach, w odwadze będąc zawsze prawdziwą ofiarą przykładu. Miał ten pan wszystkic przymioty wiclkicgo wodza, alc tych nigdy nic miał wystarczających, co nimi zasługiwać nalcży na pochwałę rzctclną króla. Nadęty szczçścicm dobrcgo powodzenia swej szabli, uniesiony świetnym blaskiem tronu, rozumiał, żc fortuna jego poddanka, a z tych powodów zaćmiwszy przezorność polityka, łatwowierny na podstępy gabinetów postronnych i domowych zazdrośników, zamysły swoje widział z żalem, że były daremnymi. Miał chciwość zbiorów, bo był królcm ubogim i był ojccm familiji, zawarł traktat o granicę z narodem mającym nazwisko od stolicy miasta [Moskwą - B. T.], z utratą prowincyjów i z miastem ich pierwszym, w nadzici pozyskania krajów prawem dzicdzicznym swemu domowi od potencyi, z którą szczęśliwie wojował. Uratował dziclnością i umicjętnością swojego wojska tron monarchy najpicrwszcgo mic̨dzy panującymi, ratując od dobycia miasto mieszkania jego; zawsze szcz̨̧śliwy w prowadzeniu wojny, zawsze cicrpi szczęście zawodne w ułożeniu rzeczy radą i przezornością. Cierpiał wicle od osób zostających pod berłem jego, osobliwie dom jeden księstwa wielkiego sprzymierzonego w narodzic czynił z królem tym spór między powaga tronu podstawiając swoje możnowładztwo, na koniec cierpicć musiał niesnaski domu własnego. Umarł okryty chwałą bardziej wspartą na okazałości świetnicj dzicł wielkich, jak istotnic pożytecznych dla swcgo narodu" (Tron dla próżnej powagi..., opr. B. Treger, „Napis”, scria IV, 1998, s. 100-101; por. takżc hasło Groby w Niektórych wryrazach..., op. cit., s. 67-68).
} 
cnoty i sławy. Żółkiewski ów wielki hetman, który żyć umiał i umierać potrafił za Ojczyznę, dziadem był z liniji matki Jana Sobieskiego. Gdy poległ pod Czecora, ciało pochowane równo z zabitym synem wspólny pokrywał grób, ten na sobie wyrażony pokazując napis: Exoriare aliquis nostris ex ossibus ultor ${ }^{5}$. Chwała tej zemsty była przygotowana od Opatrzności Janowi Sobieskiemu; ile razy wejrzał na ten testament grobu dziada swojego, żywa krew w młodości poruszała serce szlachetne do zemsty, która wtenczas tylko jest cnotą, gdy się łączy za krzywdę domu i krzywdę Ojczyzny razem. Podobne miał przykłady chwały poprzedników imienia swojego: dziad jego Marek Sobieski wojewoda lubelski, ojciec Jakub Sobieski kasztelan krakowski, zasługami równo jako i wiadomością nauk dobrze znajomy krajowi. Ten z Teofili Żółkiewskiej małżeństwa córki hetmana Żółkiewskiego miał dwóch synów Marka i Jana.

Edukowanie tych młodych następców na dostatki i dostojeństwa znaczne w Ojczyźnie dostało się Akademiji Krakowskiej. Tam było pierwsze oświecenia miejsce, gdzie nauki i cnoty wiadomość brali pod Wojciechem Dąbrowskim, mężem cnotą i umiejętnością dobrze zaszczyconym. Szczęśliwy stan mój akadem[icki], że miał okazyją przyłożyć się przysługą wielkiemu narodu swojego królowi, ale szczęśliwy i Jan Sobieski, że brał prawidła nauki i cnoty w ojczystej narodu swojego szkole, tak jak niemowlę, które piersią własnej matki karmione zostaje. Umknięcie się teraz w wieku naszym od edukacyi powszechnej, chociaż wolą stanów R[zeczy]p[ospo]l[i] tej ułożonej, jest skutkiem nieszczęśliwego uprzedzenia, wyszukiwanie inszej domowej i prywatnej jest przeto tym samym, co żądanie napoju w gorączce. W pierwiastkowych dniach życia Jana Sobieskiego widać było związek duszy i ciała jego w stopniu natury takim: żywość prędka, chęć chwały, czuły na poniżenie, siły mocnej i zdrowia takiegoż, postać wymiarkowana jako zwyczajne siedlisko powagi, kto ma królować.

W latach młodzieństwa posłani obydwa bracia do Francyi, aby doskonalić nauki pokoju i uczyć się nauki wojny, według zlecenia ojca tak mówiącego do synów, aby się wszystkiego uczyli prócz tańców, których się mieli z Tatarami uczyć. Jakoż tak uczynili, nie zarzucając czasu tłumem tych zabaw, co wzbudzają, żywią i umacniają namiętność w młodych; weszli w liczbę muszkietyjerów u dworu francuskiego, gotując sobie sposobność w stanie żołnierskim dopełnienia zręczniej usług w ojczyźnie własnej. Z Francyi do Stambułu obrócona podróż, aby tym zdarzeniem przejrzeć potęgę narodu tureckiego naówczas groźnego Polszcze i Europie całej. Żądaniem było jeszcze młodych Sobieskich widzenie Azyi, gdy wiadomość okropna przychodzi o zajętej wojnie na granicach polskich; jeszcze to były reszty owego szczęśliwego wieku, gdy młodzież gotowa była przelewać krew dla swojej ojczyzny, i śmierć, która jest długiem natury, na obronę kraju podejmować. Już powróciwszy, nie mieli pociechy uściskać ojca swojego; umarł ten wielki mąż, zostawując synom dziedzictwo majątku, sławy, zasługi, i pamięć wyrobioną z samego wyboru cnót.

Czas ów napełniał posępnemi zdarzeniami wszystkie prawie narody w Europie. Filip IV król Hiszpaniji stracił Portugaliją; kłótnie we Francyi wygnały matkę Ludwika XIV z stolicy państwa; Karol I w Angliji głowę stracił pod ręką kata; w Polszcze wojska zniesione i hetmani wzięci

5 Verg. Aen. IV, 625. 
w niewolę przez zbuntowane na Ukrainie chłopstwo i Tatary. W takim stanie zastali Ojczyznę młodzi Sobiescy, których matka i w rozrzewnieniu macierzyńskiej miłości, i w poruszeniu niebezpieczeństwa Ojczyzny w takich wyrazach wita: „Przyjdźcie zemścić się za nas; ja was nie uznam za synów, jeżeli podobni będziecie rycerzom pod Pilawcami" ${ }^{6}$.Wzięły skutek słowa wielkiej matki u godnych synów. Pierwsza potyczka z Tatarami kosztowała jednego z nich wolność i życie, to był Marek Sobieski, który zginął w niewoli. Jan zaś pozostały, już naówczas starosta janowski, pokazywał początkowe dzielności swojej znaki, w odwadze widać było żołnierza, a w przezorności wodza. Przypadek odkrył go, jak w krótkim czasie zjednał sobie osoby swojej wziętość. Wojsko zbuntowane pod Zbarażem, nie dbając na Czarneckiego namowy, nalegania i groźby, Sobieskiego usłuchało natychmiast. Tu widać było całą wielkość duszy jego. Przywieść ludzi broń trzymających w ręku do pokoju, pozyskać, żeby wyznali swój błąd, trzeba mieć wielką przemoc nad umysłami, co sprawić tylko może albo powaga już doświadczona, albo odważna nadzieja, że się jest powszechnie kochanym. Posłuszeństwo od wojska powrócone wodzom zatrzymało zwycięstwa kozackie, i los tej wojny łaskawszym się pokazał Polszcze. Przed przymierzem zborowskim został Jan Sobieski chorążym koron[nym], biorąc dostojność w królestwie jako prawdziwą nagrodę swojej zasługi. Dalsze obroty wojny z Szwedami, Rakoczym, Moskwą, Prusakami pomnażały i męstwo Sobieskiego, i z męstwa pochodzące zasługi, których sprawiedliwym szacunkiem został marszałkiem koron[nym], a potym najwyższym hetmanem wojska. Po przymierzu oliwskim z narodami wojującemi, po uspokojonej wrzawie domowej między Lubomirskim i królem, Jan Kazimierz złożył koronę, tron za spokojność mieniając. Wyniesienie ks[ię]cia Michała Wiśniowieckiego wolnym wybrania głosem obiecywało uszczęśliwienie kraju, jeżeli nadzieja może być zawsze matką szczęścia; tu skutek nadziei nastąpił przeciwny. Kozacy zburzeni nowym buntem opuszczają panowanie Polaków, władzę Turków obierając na to miejsce.

Mahomet IV nastąpił na tron naówczas, depcąc po ciele ojca swojego Ibrahima, którego janczarowie udusili. Mahomet poznosił wojska cesarskie, pozdobywał wiele prowincyi w Węgrzech i wyspę Kandyją zawojował. Mahomet był niezwyciężony, lubo nic sam przez się nie robił. Szczęście zdawało się być nieodstępne w ręku wezyra Kupruli wodza i ministra największego, jakiego tylko kiedy mogły mieć państwa otomańskie. Wojna wypowiedziana Polszcze ze strony Turków, a w takim czasie, kiedy przeciwko królowi nienawiść, zazdrość, pycha uzbroiła ręce jednej części narodu, a kiedy druga część staje przy obronie króla, w tym stanie rozdwojonemu narodowi opierać się siłom Azyi niepodobieństwem było. Stracony Kamieniec, Podole i Ukraina, a z reszty królestwa hołdu wyznaczona opłata. Sejm uspokojenia nastąpił, na którym Sobieski wymową, płaczem, naleganiem wymógł odrzucenie budziackiego traktatu ${ }^{8}$. Zgromadzone wojska Polski i Litwy pod Glinianami, wyprawione ku brzegom Dniestru pamiętną bitwą pod Chocimem

\footnotetext{
${ }^{6}$ W bitwie pod Piławcami we wrześniu 1648 roku wojsko koronne uciekło tchórzliwie na samą wieść o zbliżaniu się Tatarów.

${ }^{7}$ Kreta, od włoskicj nazwy wyspy Candia, która z kolei bierze się od nazwy miasta, dzisiejszego Iraklionu (w starożytności Heraklejon).

${ }^{8}$ Whaściwic buczackiego, bo zawartego 16 paździcrnika 1672 roku w Buczaczu na Ukrainic.
} 
wygrały, a król Michał we Lwowie żyć, cierpieć i królować przestal ${ }^{9}$, a zwycięski wódz najsprawiedliwszym głosem wybrania na tron wstępuje. Takie nagrody warte były wielkiego bohatyra dzieła i takiego króla zdawała się wymagać potrzeba narodu: kto umie bronić szczęśliwie, potrafi i rządzić bezpiecznie. Dowodu tego król Jan pokazał skutek, nie pierwej przyjmując koronę złotą na głowę, dopóki wojna turecka nie wzięła poparcia pod oczami przytomnego króla.

Mahomet nie myślał mścić się zbitego wojska swojego pod Chocimem, Kupruli wezyr jego już umarł, szczęście państwa tureckiego zaczęło słabieć, a król Jan Ukrainę odzyskał. Kto wysławić godnie może prace wojującego króla i wiążące się z niemi niewygody? W czasie zimy, miasto powrotu do stolicy, Bracław miasteczko źle budowane wyznacza na kwaterę dla siebie; podobno rzemieślnik najpodlejszy w Warszawie znalazł się lepiej mięszkającym w tym razie od swojego własnego króla. Odparty zwycięstwy nieprzyjaciel, a król złotą ozdobiony koroną. Na koniec rozczyn wojny pod Żurawną Polskę od nikczemności holdu uwolnił, i odetchnąć pozwolił narodowi kilkoletnim pokojem. W tym państwie tureckim posiad[t]szy urząd wezyra, Kara Mustafa, uprzykrzywszy trudy wojenne z Polską, umyślił wojnę przeprowadzić do Niemiec naprzeciw państwom Leopolda cesarza. Rokosze królestwa węgierskiego, nieprzychylność Francyi, rząd inszy od dzisiejszego, mniej pieniędzy i wojska, wszystko to w państwach austryjackich obiecywało niebezpieczną mieć wojnę. W tym stanie rzeczy znajdującym się w Niemczech Kara Mustafa wielki wezyr bierze komendę nad wojskami krajów tureckich. Nigdy pycha, łakomstwo nie miało przestrzeńszego pola jak w sercu tego wezyra, 140 tysięcy wojska regularnego janczarów i spahów ${ }^{10}, 18$ tysięcy Wołochów i Mołdawczyków, 15 tysięcy Węgrów pod Tekielim, 50 tysięcy Tatarów z chanem Selim Gerej, 300 sztuk harmat, wyprawa wielka, ale też to wyprawa na zawojowanie zachodniego państwa. Ogłoszona ta wojna wprowadziła króla Jana i naród nasz polski w sprzymierzenie z Leopoldem cesarzem na obronę domu jego i państwa. Wezyr, wszedłszy do Węgier, spiesznym przechodem wojska swojego dążył do oblężenia Wiednia. Książę lotaryński na czele wojska austryjackiego, nie mogąc wstrzymać wielkiego zastępu wojsk tureckich, częścią piechoty opatrzywszy Wiedeń, przechodzi Dunaj za miasto, a na jego miejsce następują Tatarzy. Tu patrzać można było na widok, który Opatrzność sporządza dla nauki monarchów i dla rozrzewnienia ludu ich, że musi ten westchnąć i zapłakać tych samych panów, których nie spodziewał się godnych swego politowania. Leopold najmocniejszy cesarz po Karolu V uciekając z stolicy państwa swojego z żoną i z matką żony swojej, z arcyksiężniczkami, z familiją i z dworem, połowa większa obywatelów w zamięszaniu i trwodze udaje się za nim, wszystkie przyległości zastąpione ciżbą pojazdów i podwód, resztę niedobrze dążącego ludu zagony tatarskie w niewoli na odwrót do obozu prowadzą.

Cesarz na wstępie samym wojny nie spodziewał się tak nagłego posunienia się wojsk tureckich; król Sobieski, mając o tym wiadomość, jako zwyczajnie lepsząją mieć mogą ci, co sami przytomni osobą swoją wojują, przestrzegał Leopolda, ale daremnie. Rząd bronienia miasta był w ręku

\footnotetext{
${ }^{9}$ Sformułowanic powtarzające siç w innych dziełach kanonika. Odpowiednie przykłady zob.: B. Treger, Kollątaj czy Jezierski? Zagadnienie autorstu’a „Tronu dla próżnej pouvagi...”, „Napis”, scria IV, 1998, s. 83.

${ }^{10}$ Spahowie lub spahisi — nieregularna jazda turecka złożona z lenników sułtana.
} 
hrabiego Starenberga, wojsko austryjackie za Dunajem z książęciem swoim Karolem lotaryńskim, a wezyr całym zastępem ludu swojego wokoło obległ miasto. Wszystko w tak wielkim obfitowało obozie, dostatek niezmiernej żywności i broni, rozległe namioty baszów, piękny czyniąc widok, niknęły przed wielkością namiotu wezyra; rozległość jego równała się wielkości miasta, widać w nim było łaźnie, fontanny, ogrody, i co tylko zbytek Azyi gustowi przystawić może. Miękkość życia wezyra nie przeszkadzała męstwu janczarów, ich odwagą miasto ściśnione, bojaźnią upadku swego przeraża się, wpośrzód zaś niebezpieczeństwa jego i największej potrzeby Jan III ruszył z wojskami z granic polskich, barziej jeszcze politowaniem i ludzkością wzruszony niżeli obowiązkami przymierza. W piąciu mil odległości od Wiednia obleczonego ${ }^{11}$ złączywszy się z wojskami cesarskiemi i przeprawiwszy Dunaj, przedsięwziął wydanie generalnej bitwy. Złączone wojska niemieckie i polskie miały 74 tysiące ludu, czterech monarchów i 26 książąt z domów panujących. Przed przybyciem królewskim zamięszanie było o najwyższą zwierzchność nad wojskiem; przyzwoitość króla wzięła to przyzwoite dla siebie miejsce, i wkrótce wyrok wyszedł od niego, aby wojska do potyczki szły takim porządkiem: Śrzodek szyku trzymać będą wojska cesarstwa z przydanemi niektóremi regimentami polskiemi, rząd nad niemi pod księciem Karolem [z] Lotaryngiji; polskie wojska wezmą skrzydło prawe pod Jabłonowskim hetmanem; lewe skrzydło Bawaryi, Saksoniji elektorowie prowadzić mają; tylną straż cyrkułów Imperii ludzie zastapili. W tym rozrządzeniu po przykrym przechodzie gór stanął król Jan na Kalemberku najprzyleglejszej górze pod Wiedniem; tak wolne i wyniosłe miejsce godziną przed zachodem słońca chrześcijanom odkryło widok jeden z najpiękniejszych i najokropniejszych razem potęgi i nikczemności ludzkiej. Obszerne pole i wyspy Dunaju okryte namiotami, których wspaniałość zdając się być miejscem rozkoszy, nie przestaje zostawać okrucieństwa przybytkiem, przy tym niezmierność koni, wielbłądów, bawołów i mułów, dwakroć sto tysięcy ruszających się pod bronią ludzi, huk harmat dobywających i broniących fortecy, miasto okryte kurzawą, dymem i ogniem; znaki upewniły oblężonych [o nadejściu] odsieczy. Trzeba długie wytrzymać oblężenie, i w ustawicznej zostawać śmierci trwodze albo niewoli, żeby uczuć taką radość, jaką wiedeńczykowie uczuli. Król Jan, uważywszy stan obozu, rzekł do książąt i generałów: „Ten człowiek źle się położył z wojskiem, on nic nie umie, my go pobijemy”. Kto ma zwierzchność nad wojskiem w tak ścisłej potrzebie, a nie umie prorokować tak jak Jan III, powinien porzucić komendę.

Bicie $z$ harmat wzajemne $\mathrm{z}$ obojej strony zaczynało dzieło następującego dnia - ten był 12 września, od którego zawisło, czyli Wiedeń miał być pod Mahometem IV, tak jak Carogród pod Mahometem II, i czyli państwo zachodnie miało się złączyć ze wschodnim, i na koniec czyli Europa miała być chrześcijańską albo nie. Na dwie godziny przed tym strasznym dziełem król Jan III, książę lotaryński i wielu generałów uczyniło powinność religiji mało praktykowaną za naszych czasów, to jest udali się do Syna Boskiego, łącząc się z nim przez przyjęcie sakramentów ołtarza. O wschodzie samym słońca wojska obudwu narodów, schodząc z góry, postępowały ku Turkom; ognia z harmat i z ręcznej broni podając, rozszerzają się podług objęcia miejsca,

${ }^{11}$ Tu w znaczeniu: 'oblężonego', 'otoczonego'. 
obszerna przestworność, w której Turcy w największym ruszaniu widzieli swych nieprzyiaciół, to dało sposobność chanowi postrzec proporce przed Janem III, pokazał go wezyrowi, mówiąc: „Oto król jest na czele”, słowa, które nabawiły go niespokojności. Natychmiast wezyr wydał rozkaz Tatarom mordować wszystkich więźniów, potykać się z następującym wojskiem i razem miasta dobywać. Zstępujące $z$ góry wojska chrześcijan i potykające się tureckie zaczęły krwawą robotę. Pierwsze linie piechoty z tą gwałtownością wydały ognia, że zraziwszy tureckie hufce, dały sposobność wstąpić w bitwę kawaleryi z wygodnym rozpostarciem się. Gdyby sztukę wymowy zamienić teraz można w zwierciadło, widzielibyśmy króla Jana przebiegającego szyki, upatrującego potrzeby, wydającego rozkazy, przywodzącego roztropnie i odważnie. Wśrzód tak okrutnego dzieła w wojsku tureckim basza Dyjarbeku ${ }^{12}$ sprawował prawe skrzydło, basza budziacki ${ }^{13}$ lewe, wezyr śrzodek utrzymywał wojska. Dwie potęgi w równym losu jeszcze zostawały stanie, gdy wśrzód wrzasków i muzyków tureckich podczas tak okropnego momentu pokaże się namiot czerwony i chorągiew poświęcona Mahometa obrządkiem. To narzędzie fanatyzmu, które tylu wieków wzbudzało dzielność w ich sercach, w tej bitwie już wyrabiać zadurzenia tego nie mogło. Król Jan III postrzegłszy to, rozkazał zaraz kawaleryi swojego narodu szablą w ręku przedzierać się przez zastęp niewiernych z największą natarczywością: pełni to jazda polska, zmięszani Turcy ustępują, namiot się obala, choragiew niknie, wezyra niebezpieczeństwo otacza, zaczyna się porywcze zamięszanie, trwoga przechodzi od śrzodka wojska do skrzydeł, strach, ucieczka, noc, Turków już nie masz i Wiedeń ocalony zostaje.

Tak wielkiego dzieła wykonanie przywodzi nam chwałę narodu i króla, widać wielkie przymioty duszy jego, szczęście i zręczność do wojny, miłość narodu i miłość chwały dla narodu swego. Od tej przegranej przerwal się przeciąg zdobyczów tureckich. Cokolwiek w tym wieku zdobyli, wszystko w tym wieku stracili, i zdaje się, jakoby zamach Jana III przeciął uszczęśliwienie państw tureckich, i to jest epocha w dziejach narodów, którą dzisiaj obchodziemy.

\footnotetext{
12 Dijar Bakr - dosłownic „terytorium plemienia Bakr” (zob. J. i D. Sourdel, Cywilizacja islarnu (VII-XIII w.), tł. M. Skuratowicz, W. Dembski, Warszawa 1980, s. 455), dziś Diyarbakir w południowowschodnicj Turcji nad Tygrysem.

13 Budziak - równina mic̨dzy Dniestrem a morzem Czarnym.
} 


\section{Notka edytorska}

Profesor Andrzej Feliks Grabski zastanawiał się:

Jak oceniał F. S. Jezierski bieg dziejów polskich? Przestało niestety istnieć źródło, które mogłoby nam pomóc w uzyskaniu odpowiedzi na postawione pytanie. W. Smoleński znał jeszcze przechowywaną w rękopisie Biblioteki Ordynacji Krasińskich Mowę Imci xiędza Jezierskiego, rektora akademii lubelskiej, na pochwatę króla Jana III $w$ dzień stuletniego aniwersarza (12 września 1783r.) zwycięstwa nad Turkami pod Wiedniem, w związku z którą zanotował: „Wyłożył w niej Jezierski pogląd swój na dzieje Polski, wskazywał wadliwości w ustroju Rzeczypospolitej, chłostał szlachtę, a w końcu przedstawił życiorys Sobieskiego". Rękopis tej mowy uległ zniszczeniu w 1944 roku, jest to więc jedyna, niestety bardzo lapidarna, informacja o jej treści ${ }^{1}$.

Okazuje się jednak, że będzie można ocenić, czy wspomniana mowa wzbogaci wiedzę o poglądach Jezierskiego na bieg dziejów polskich.

Przemysława Matuszewska w rozprawce o Jezierskim podaje informację, iż Mowa... na pochwatę króla Jana III $w$ dzień stuletniego aniwersarza zwycięstwa nad Turkarni pod Wiedniem zachowała się w manuskrypcie, który posiada Biblioteka Ukraińskiej Akademii Nauk w Kijowie (Archiwum Chreptowiczów, sygn. I 6060) ${ }^{2}$. Przy okazji publikacji dwóch innych wystapień trybunalskich kanonika niżej podpisany wyraził opinię, iż „Jako zadanie na przyszłość należy potraktować edycję rękopisu kijowskiego (...)”3. Chciałbym w tym miejscu podziękować doktorowi Mariuszowi Affkowi z Instytutu Historii Nauki PAN, który przychylił się do mojej prośby i przywiózł z Kijowa mikrofilm manuskryptu, co umożliwilo szybszą realizację wspomnianego zadania. Mikrofilm ten zostanie przeze mnie przekazany do czytelni mikroform Biblioteki Narodowej w Warszawie.

Rękopis, jak to wynika $z$ porównania $z$ listami autora Rzepichy..., nie jest autografem. Jego odczytanie nie sprawia żadnych problemów. Cała mowa została zapisana wyraźnym charakterem z niewielką ilością poprawek na 15 foliowanych kartach. Tytuł: Mowa przy obchodzeniu pamiątki stu lat zwycięstwa pod Wiedniem Jana III, miana $w$ Lublinie przez ks. Jezierskiego rektora różni się od tego, który podał Smoleński, a za nim Matuszewska. To rzecz zwyczajna w przypadku rękopiśmiennej literatury okolicznościowej. Sygnatura wymieniona w Pisarzach polskiego oświecenia zgadza się z faktyczną.

Wobec ogromu literatury o Sobieskim i odsieczy wiedeńskiej nie wydawało się celowe przeciążanie tekstu mowy przypisami. Wystąpienie Jezierskiego można łatwo skonfrontować z dzisiejszym stanem badań, sięgając na przykład do prac Zbigniewa Wójcika (Jan Sobieski 1629-1696, Warszawa 1994 - tu obszerna bibliografia) oraz Jana Wimmera (Wiedeń 1683. Dzieje kampanii i bitwy, Warszawa 1983).

\footnotetext{
${ }^{1}$ A. F. Grabski, Myst historyczna polskiego oświecenia, Warszawa 1976, s. 242-243. Autor powoluje się tu na pracę W. Smoleńskiego, Kuźnica Kottątajowska, w: idem, Wybór pism, Warszawa 1954, s. 280.

${ }^{2}$ Zob. P. Matuszewska, Franciszek Salezy Jezierski, w: Pisarze polskiego oświecenia, red T. Kostkiewiczowa, Z. Goliński, t. 2, Warszawa 1994, s. 658.

${ }^{3}$ B. Treger, Kaznodzieja i prześmiewca. Uwagi o niektórych zagadnieniach twórczości i życia Franciszka Salezego Jezierskiego, „Napis”, seria V, 1999, s. 97.
} 
Pisownia i interpunkcja została zmodernizowana, tak by nie naruszyć żadnych ważnych własności osiemnastowiecznej wymowy, fleksji i składni. Niniejsza publikacja zalicza się, ogólnie rzecz biorąc, do rodzaju określonego w Zasadach wydawania tekstów staropolskich ${ }^{4}$ jako typ B. Uwzględniono ponadto dodatkowe reguły zaproponowane przez Janusza Maciejewskiego 5 .

${ }^{4}$ Zob. Zasady wydawania tekstów staropolskich. Projekt, red. M. R. Mayenowa, Wrocław 1955.

${ }^{5}$ Zob. J. Macicjewski, Zasady edycji okolicznościowejliteratury politycznej XVIII uieku, „Napis”, scria III, 1997, s. $185-192$. 